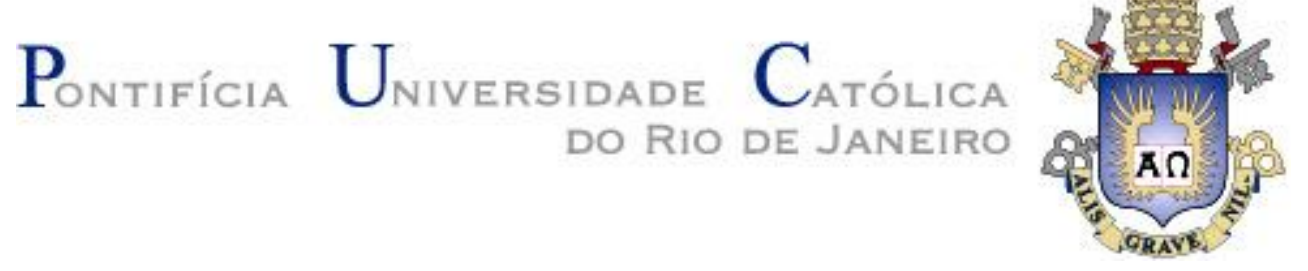

Helena Carneiro Aguiar

\title{
QUANDO A PARTIDA ANTECEDE A CHEGADA: SINGULARIDADES DO ÓBITO FETAL
}

Dissertação de Mestrado

Dissertação apresentada como requisito parcial para obtenção do grau de Mestre pelo Programa de Pós-Graduação em Psicologia (Psicologia Clínica) do Departamento de Psicologia do Centro de Teologia e Ciências Humanas da PUC-Rio. Aprovada pela comissão Examinadora abaixo assinada.

Orientadora: Prof ${ }^{a}$. Silvia Maria Abu-Jamra Zornig 


\section{Pontifícia Universidade Católica $_{\text {a }}$

Helena Carneiro Aguiar

\section{QUANDO A PARTIDA ANTECEDE A CHEGADA: SINGULARIDADES DO ÓBITO FETAL}

Dissertação apresentada como requisito parcial para obtenção do grau de Mestre pelo Programa de Pós-Graduação em Psicologia (Psicologia Clínica) do Departamento de Psicologia do Centro de Teologia e Ciências Humanas da PUC-Rio. Aprovada pela comissão Examinadora abaixo assinada.

Profa. Silvia Maria Abu-Jamra Zornig

Orientadora

Departamento de Psicologia - PUC-Rio

Prof ${ }^{a}$ Sara Angela Kislanov Departamento de Psicologia - PUC-Rio

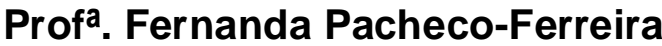

Programa de Pós-Graduação em Teoria Psicanalítica - UFRJ

Prof $^{\mathrm{a}}$ Andrea Seixas Magalhães Departamento de Psicologia - PUC-Rio

Profa Denise Berruezo Portinari Coordenadora Setorial de Pós-graduação

e Pesquisa do Centro de Teologia e Ciências Humanas - PUC-Rio 
Todos os direitos reservados. É proibida a reprodução total ou parcial do trabalho sem autorização da universidade, da autora e da orientadora.

\section{Helena Carneiro Aguiar}

Graduou-se em Psicologia no ano de 2005 pela Universidade Federal do Rio de Janeiro (UFRJ). Especialista em Psicoterapia na Infância e na Adolescência pelo Instituto Fernandes Figueira/Fiocruz. Dedica-se atualmente à Psicologia Clínica e Hospitalar Neonatal e pesquisas acadêmicas no campo da Psicologia/Psicanálise.

Ficha Catalográfica

Aguiar, Helena Carneiro

Quando a partida antecede a chegada: singularidades do óbito fetal / Helena Carneiro Aguiar ; orientadora: Silvia Maria Abu-Jamra Zornig. - 2016.

89 f. ; $30 \mathrm{~cm}$

Dissertação (mestrado)-Pontifícia Universidade Católica do Rio de Janeiro, Departamento de Psicologia, 2016.

Inclui bibliografia

1. Psicologia - Teses. 2. Luto. 3. Melancolia. 4. Objeto virtual. 5. Espaço transicional. 6. Criatividade. I. Zornig, Silvia Maria Abu-Jamra. II. Pontifícia Universidade Católica do Rio de Janeiro.

Departamento de Psicologia. III. Título. 
Dedico este trabalho às famílias que perderam seus bebês em sua espera, especialmente àquelas do grupo "Do luto à luta: apoio à perda gestacional", com quem tenho a grande honra de compartilhar suas histórias e estar junto nessa luta pelo luto. 


\section{Agradecimentos}

À Silvia Zornig, pela valiosa e competente orientação, apresentando-me autores e conceitos psicanalíticos importantes na elaboração deste trabalho e permitindo-me um amadurecimento teórico-clínico.

À CAPES, pelo financiamento desta pesquisa.

À PUC-Rio, pelos auxílios concedidos e espaço altamente acolhedor e eficiente voltado ao aluno.

Aos colegas do grupo de pesquisa, por dividirem expectativas e angústias ao longo deste período. Em especial, à querida amiga Natália Cidade, pela leitura atenta ao meu trabalho e incentivo constante.

À psicóloga Rene Góes, por ter, há muitos anos, despertado-me à Psicologia hospitalar, mantendo-se como exemplo profissional e sendo sempre uma motivação.

À psicóloga Denise Morsch, por confiar em minha potencialidade, apostar nas mudanças e pela inspiração através de seu conhecimento e dedicação à Psicologia Perinatal.

Às famílias que sofreram perdas fetais, com as quais tive a honra de conhecer suas histórias, seja pela escuta de relatos, acompanhamento psicoterápico ou acompanhamento hospitalar.

À querida e amada tia Maury, pelo auxílio inestimável com a bibliografia em francês desta dissertação.

À Marília Aguiar, pelas sugestões bibliográficas e acolhimento nos congressos em Belo Horizonte.

Aos meus pais e irmãs, por sempre acreditarem em mim e valorizarem minhas conquistas, com orgulho.

Ao Álvaro, meu marido, por todo amor, compreensão e incentivo sempre.

Ao Pedro, meu filho amado, por ser "meu companheirinho de todas as horas". 


\section{Resumo}

Aguiar, Helena Carneiro; Zornig, Silvia Maria Abu-Jamra (Orientadora). Quando a partida antecede a chegada: singularidades do óbito fetal. Rio de Janeiro, 2016. 89 p. Dissertação de Mestrado - Departamento de Psicologia, Pontifícia Universidade Católica do Rio de Janeiro.

O presente trabalho tem como finalidade refletir sobre as particularidades e vicissitudes do óbito fetal, destacando o estatuto virtual do objeto perdido (embrião ou feto). O óbito fetal ocorre justamente no momento marcado por oscilação entre dimensões de indiferenciação e de diferenciação. A gravidez suscita uma nova organização psíquica, visando à construção da parentalidade e a interrupção abrupta deste processo durante a gestação exige um trabalho de elaboração psíquica bastante singular. A dificuldade em lidar com o óbito fetal afeta a todos os envolvidos - evidentemente os familiares, mas também os profissionais de saúde. Algumas vezes, o trabalho de luto pode não ser possível pela dificuldade de inserir o evento em uma cadeia simbólica que permita sua elaboração e introjeção. Nesses casos, destaca-se a via da melancolia por constituir-se uma opção, por vezes, mais disponível aos pais diante da morte do filho. Na melancolia não está claro o que foi perdido, a perda é recusada e, através da identificação narcísica, o melancólico mantém o objeto dentro de si. Os pais que perderam tão precocemente seus filhos terão que descobrir uma forma de fazer face ao insuportável desta perda, destacando-se a importância de uma saída criativa.

\section{Palavras-chave}

Luto; melancolia; objeto virtual; espaço transicional; criatividade. 


\section{Abstract}

Aguiar, Helena Carneiro; Zornig, Silvia Maria Abu-Jamra (Advisor). When departure preceding the arrival: singularities of fetal death. Rio de Janeiro, 2016. 89 p. MSc. Dissertation - Departamento de Psicologia, Pontifícia Universidade Católica do Rio de Janeiro.

The aim of this paper is to reflect on the particularities and vicissitudes of fetal death, focusing on the virtuality of the lost object (embryo or fetus). Fetal death occurs in a moment of oscillation between differentiation and undifferentiation. During pregnancy the psychic structure begins to change in order to prepare the future parents for the maternal and paternal role. Fetal death abruptly interrupts this process, thus demanding a particular psychological work. Dealing with fetal death affects everyone around, although more evidently the family, but also health professionals. Sometimes, the mourning may not be possible, because it may be difficult to include the event in a symbolic chain that allows its development and internalization. In such cases, the path of melancholy stands out, because often its an easier option for parents. In melancholy, what was lost is not clear, loss is refused by a narcissistic identification; melancholic people maintain the object inside. Parents who lost their children so early have to find a way to cope with the unbearable, and the importance of creative possibilities should be highlighted.

\section{Keywords}

Mourning; melancholy; virtual object; transitional space; creativity 


\section{Sumário}

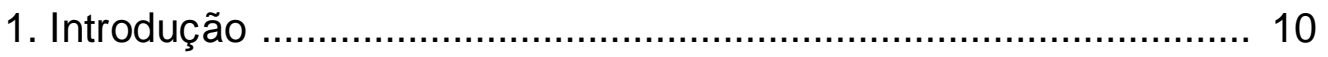

2. Primórdios da maternidade ....................................................... 15

2.1 Gestação e constituição psíquica ............................................ 15

2.2 Bebê: entre o familiar e o estranho ............................................. 22

2.3 Virtualidade: o bebê enquanto promessa .................................. 27

3. Quando a morte interrompe o processo ……………..................... 31

3.1 Vida e morte sobrepostas ……………………..................... 31

3.1.1 O impacto do óbito fetal na família ................................ 35

3.1.2 O impacto do óbito fetal no profissional de saúde ......... 41

3.2 A interrupção de uma promessa …………………………....... 45

3.3 Trabalho subsequente à perda do objeto de amor ....................... 50

3.3.1 Introjeção x incorporação ............................................ 56

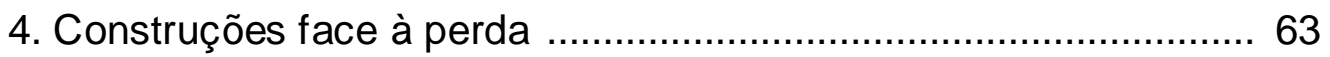

4.1 Criatividade e espaço potencial ................................................. 63

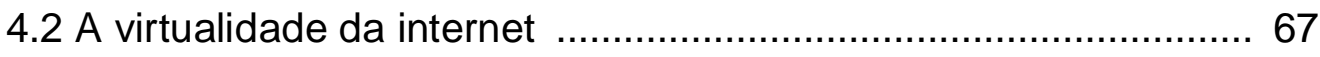

4.3 Possibilidades terapêuticas ................................................... 70

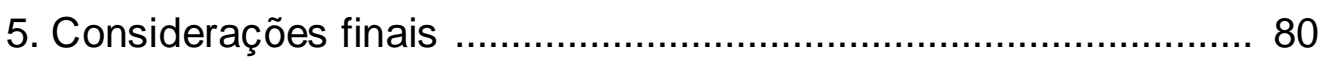

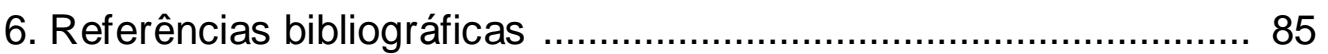


Ao compartilharmos o desejo pela sua chegada,

Já preparamos a sua doce morada.

Ao compartilharmos os planos pra te receber,

Nunca pensamos em te perder.

Ao compartilharmos os sonhos pela maternidade,

Sinto-me mãe de verdade.

Ao compartilharmos a sua presença,

Não vislumbramos a possibilidade da sua ausência. Ao compartilharmos o quanto sonhamos com o dia ao te embalar,

É impossível não te amar.

Ao compartilharmos todas as mudanças advindas com a gravidez,

Sinto que finalmente chegou a minha vez. Ao compartilharmos todas as transformações corporais, hormonais e emocionais,

Percebo o quanto este momento é especial, sobrenatural, fora do normal.

No entanto, como compartilhar a interrupção de uma vida,

Que está sendo sentida, vivida e querida?

Como compartilhar todo o amor transformado em dor?

Como compartilhar o sonho interrompido,

As noites mal dormidas?

Como compartilhar o sentimento de angústia pelos planos a sucumbir? Como compartilhar a nossa descrença na vida, no homem, a falta de desejo pelo que está por

É melhor o silêncio e a solidão?! Mas foi tudo compartilhado outrora,

E agora?

Larissa Lupi, Maternidade compartilhada 


\section{Introdução}

A partir de uma vivência profissional junto a famílias que perderam seus bebês ainda no ventre materno, o interesse por investigar certas questões específicas sobre a morte fetal e as formas de lidar com essa perda foi despertado e estabeleceu-se como forte motivação para a realização deste estudo. Através do acompanhamento de famílias enlutadas em uma maternidade do Rio de Janeiro e do contato com o testemunho de mulheres em um grupo de apoio à perda gestacional na internet, tivemos contato com a dor e as dificuldades impostas diante da perda de um filho que vinha sendo sonhado e esperado.

Com o intuito de elucidar o campo que decidimos estudar, cabe ressaltar que refletiremos especialmente sobre o impacto produzido no psiquismo dos pais diante de uma perda fetal. Ao longo do trabalho utilizaremos um levantamento bibliográfico para nos auxiliar no entendimento da representação desta perda no psiquismo dos pais e o processo subsequente a esta perda, assim como traremos breves ilustrações clínicas de casos atravessados pelo óbito fetal. Sabemos que cada perda será vivida de forma particular por cada família e não almejamos, de forma alguma, esgotar a problemática nos casos trazidos. O objetivo dessa estratégia será ilustrar questões que são recorrentes diante das perdas fetais, para que possamos pensar teoricamente sobre estas.

Ao nos referirmos ao óbito fetal, é importante pensarmos sobre o que estamos considerando como essa morte específica. Segundo a definição do Ministério da Saúde (BRASIL, 2009, p. 7), óbito fetal é descrito como "óbito intraútero, ocorrido a partir da $22^{\mathrm{a}}$ semana completa de gestação, ou com peso igual ou superior a $500 \mathrm{~g}$, até o momento do parto". Essa é a definição utilizada aos olhos da Lei, e para ser considerado um óbito fetal, a morte deve ocorrer antes da expulsão ou de sua extração completa do corpo materno. Antes da vigésima segunda semana de gestação, se o feto morre considera-se que não havia ainda uma vida em "pleno sentido" - de acordo com tal demarcação.

No entanto, acreditamos que determinar quando a vida tem início é uma das questões mais espinhosas da atualidade e não deve ser assim simplificada. Ao redor dessa questão, surgem inúmeros dilemas éticos e religiosos. Para a igreja católica, o embrião é considerado como um ser humano desde o momento da 
fecundação. Portanto, uma morte ou interrupção, em qualquer momento da gravidez, já configuraria a morte de uma criança e implicaria, portanto, neste trabalho de luto singular a que nos propomos estudar.

Apesar do debate entre ciência e religião, acreditamos que o estatuto do feto ou do embrião só poderá ser estabelecido a partir das representações que seus pais lhes conferem, sendo realizado de maneira singular. Para alguns casais, se trata mesmo de um bebê já no início da gestação; para outros, permanece como um feto ainda sem uma antecipação de sua humanização. Levando em consideração a complexidade desse debate, consideramos como óbito fetal a morte do feto ou do embrião, em qualquer momento da gravidez, no qual os pais já possuam uma antecipação deste bebê por vir e já lhe atribuam o estatuto de filho.

No Manual de vigilância de óbito infantil e fetal, elaborado pelo Ministério da Saúde em 2009, reconhece-se que a mortalidade fetal ainda é pouco estudada e não se tem muitos dados e análises disponíveis na literatura e estatísticas brasileiras, reflexo da baixa visibilidade, interesse e compreensão em torno dessa morte específica. As constantes subnotificações do óbito fetal no nosso país (especialmente nas regiões Norte e Nordeste) comprometem o real dimensionamento do problema (BRASIL, 2009).

A taxa oficial de mortalidade fetal (contadas a partir da $22^{\mathrm{a}}$ semana de gestação) no Brasil gira em torno de onze mortes fetais para cada mil nascidos vivos, sendo ressaltado pelos próprios órgãos de pesquisa que essa taxa, na prática, é ainda mais expressiva. A morte neste período pode se dar por inúmeras razões e ainda é bastante frequente que as causas não sejam identificadas ou que sejam apontadas como inespecíficas. Quando consideramos todas as mortes intraútero, acredita-se que uma em cada cinco gestantes passam por essa experiência (BRASIL, 2012).

Vemos, então, a relevância de que mais estudos e atenção se voltem para essas famílias enlutadas. $\mathrm{O}$ atravessamento da morte nos primeiros momentos da maternidade suscita uma série de questões. A aproximação de polos supostamente tão distantes, nascimento e morte, provoca em todos os envolvidos uma vivência diferente de pesar. Que lugar esse bebê, cuja existência se deu apenas no ventre materno, passará a ocupar na história familiar? Como será a representação de tal vivência para os pais? E qual impacto essa morte terá em suas vidas? Essa 
pesquisa se propõe a pensar sobre o processo de construção da maternidade e da paternidade atravessados pelo óbito fetal, bem como sobre o trabalho psíquico e dificuldades subsequentes a essa perda, à luz da teoria psicanalítica.

Ao discorrermos sobre os primeiros tempos da maternidade, questionamos o momento a partir do qual é possível supor que os pais conseguiriam construir, em seu psiquismo, a representação do seu bebê como sujeito. Quando ocorre a passagem da percepção do feto, como parte do corpo da mãe, para o reconhecimento da alteridade, indicando uma separação mãe-feto? Esse será o primeiro ponto a ser desenvolvido neste trabalho, a fim de refletirmos sobre a natureza desta perda prematura. A morte fetal coincide justamente com o tempo do processo de passagem da criança interna à externa, real, que supostamente coincidiria com o período do fim da gestação.

Essa morte ocorre num delicado momento existencial, no qual o narcisismo dos pais é convocado à cena e, diante do temor que as feridas narcísicas suscitam, o filho surgiria como uma possibilidade de enfrentá-las e revê-las, com a esperança de um novo desfecho. No entanto, esse filho morre, desmantelando as esperanças e expondo novamente seus pais ao temor.

A representação que os pais possuem do feto também é marcada por grande ambivalência, pois ela reativa os fantasmas edípicos e o desamparo inicial. Veremos como a gestação produz mudanças importantes no psiquismo parental e convoca a necessidade de um trabalho psíquico para reconhecer o bebê enquanto objeto externo.

Devido a isso, nossa hipótese é que o óbito nesse período é potencialmente problemático e pode ser vivido como traumático, uma vez que o objeto de amor perdido não está firmemente reconhecido como objeto da realidade. Perder um objeto que, por vezes, representava uma parte de si carregada de esperança de rever suas feridas narcísicas e, por vezes, representava um ente querido, pode lançar seus pais em um estado confuso e dificultar a instauração do trabalho de luto.

Neste sentido, o início desta pesquisa abordará os primórdios da construção da maternidade, principalmente a relação entre o infantil da mãe (e do pai) e a representação psíquica do bebê, assim como a constituição de um espaço psíquico para as diversas concepções ligadas ao filho. Utilizaremos as contribuições de Sigmund Freud sobre o conceito de narcisismo e a noção de 
infantil que perpassa sua obra, assim como as perspectivas desenvolvidas por autores contemporâneos sobre a construção da parentalidade, destacando-se os trabalhos de Monique Bydlowski, Bernard Golse, Sylvain Missonnier, Sílvia Zornig e Regina Aragão.

Assim, após destacar como o processo de transição à parentalidade instaura uma neo-organização psíquica nos pais, procuraremos refletir sobre os efeitos e particularidades da interrupção abrupta deste processo pela morte do bebê que vinha sendo gestado. Dessa forma, o capítulo seguinte se dedicará à questão traumática desta perda e dos entraves à vivência do luto fetal. Procuraremos refletir sobre as singularidades encontradas usualmente em casos de óbito fetal, bem como sobre as dificuldades para a instauração do processo de luto e analisar como o luto, ou sua ausência, se instaura no psiquismo materno. Para tal, utilizaremos principalmente as contribuições de Freud presentes em Luto e melancolia (1917[1915]/1974) e dos psicanalistas franceses Marie-José Soubieux e Sylvain Missonnier.

Discorreremos sobre as dificuldades encontradas pela rede social que cerca os pais que sofrem a perda fetal, observando a frequência com que a vivência deste luto é desestimulada, que a morte do filho é descaracterizada e que o sofrimento é desvalorizado. Também discorreremos sobre as dificuldades encontradas para a confirmação da morte, provocando uma sensação de irrealidade e vazio. Percebemos que uma situação contraditória é evocada entre o intenso investimento psíquico no feto durante a gestação e o imediato desinvestimento que é imposto após o anúncio da morte. Pretendemos abordar os diferentes conflitos que os pais terão que se haver ao entrar em contato com essa morte, que os lança em um estado de confusão, sendo ainda mais difícil abandonar sua posição libidinal.

Tendo em vista as dificuldades impostas pelo óbito fetal, temos como proposta refletir sobre os obstáculos para a instauração do processo de luto e analisar como esse processo ou sua ausência se instaura no psiquismo. Pretendemos mostrar, através de ilustrações clínicas, como isso pode ocorrer. Percebemos que, não raro, esses lutos pelos fetos não são vivenciados, mantendose uma busca incessante por recuperar o objeto perdido. Essa busca e o não reconhecimento da perda frequentemente sobrecarregam a história de seus familiares, principalmente dos filhos que poderão vir após este óbito. 
Destacaremos ainda a melancolia como uma possível reação à perda de um objeto de amor. A melancolia pode se consolidar como um caminho às mães que não conseguirem iniciar um processo de luto. Como tentativa de não reconhecer a perda, podem recorrer a outros processos que não sua elaboração.

Para finalizar esta dissertação, optamos por ressaltar a importância da criatividade para o reestabelecimento da sensação de que a vida vale a pena ser vivida. O último capítulo será, assim, dedicado à questão das construções psíquicas possíveis diante de uma perda fetal, uma vez que acreditamos que os pais que perderam tão precocemente seus filhos terão que descobrir uma forma de fazer face ao insuportável desta perda. Nesse sentido, refletiremos sobre formas de atribuir novos significados a experiência vivida, destacando a importância da elaboração de uma narrativa, o uso da arte, da internet e a psicanálise. Para tal objetivo utilizaremos como referência bibliográfica Donald Winnicott, Gilberto Safra, Thomas Ogden e Wilfred Bion.

Nossa visão tem como ponto de partida minha prática profissional, como psicóloga inserida em uma instituição perinatal da rede privada no Rio de Janeiro. A quantidade expressiva de óbitos fetais revela a importância de que mais estudos sejam voltados para as famílias e para os profissionais que lidam diariamente e solitariamente com essa questão. Ressaltamos que o luto fetal merece uma atenção especial, visto que é uma perda não plenamente reconhecida e que não é abertamente apresentada. 


\section{Primórdios da maternidade}

Há um menino, há um moleque

Morando sempre no meu coração

Toda vez que o adulto balança

Ele vem pra me dar a mão

Milton Nascimento, Bola de meia, bola de gude

O tempo da gestação é considerado o primeiro capítulo de nossa história (MISSONNIER, 2007), portanto, voltamo-nos a esse momento inicial para compreender os primórdios de nossas vidas psíquicas. Parece-nos que, durante a gestação, o psiquismo materno é a via privilegiada para refletirmos sobre esse início, embora as transformações no psiquismo paterno durante a espera do bebê e o conhecimento maior do feto pela medicina também forneçam pistas do que ocorre na origem. Ao longo desse capítulo veremos como o tempo inicial da vida uterina é marcado pelo mistério e pelo desconhecimento, atrelados à constante busca de formas de contornar essa estranheza e humanizar o feto para torná-lo mais familiar.

\subsection{Gestação e constituição psíquica}

Desde o momento em que se deseja ter um filho começam a ser traçados processos psíquicos e mudanças subjetivas nos pais. O processo de tornar-se pai e tornar-se mãe, como indica Zornig (2012), é um longo percurso que se inicia muito antes do nascimento de um filho. A criança já existe no discurso dos pais mesmo antes de nascer, mediante suas expectativas e desejos. Segundo a autora, esse percurso se inicia na infância de cada um dos pais e, portanto, depende muito da história individual e do desejo destes, de tal modo não podermos pensar na parentalidade apenas associada à gestação e ao nascimento do filho.

As representações dos pais sobre os bebês se iniciam nas identificações feitas na infância. É justamente a história individual dos pais que forma a préhistória da criança, desde as brincadeiras de boneca, passando pelas fantasias adolescentes. O desejo de ter um filho reatualiza as fantasias de sua própria infância e o cuidado que receberam (ZORNIG, 2012). Dentro desta perspectiva, para que um homem e uma mulher tornem-se pai e mãe, é necessário um processo que envolva um conjunto de remanejamentos psíquicos e afetivos. 
O reconhecimento da relevância da herança das histórias paternas sobre a história da criança já estava presente nos trabalhos de Freud. Em 1914, no texto Introdução ao narcisismo, Freud reconhece que o afeto dos pais para com os filhos configura-se como uma revivescência e reprodução de seu próprio narcisismo. Os pais, então, supervalorizam o filho, colocando-o no lugar de "Sua Majestade, o Bebê", atribuindo-lhe todas as perfeições e ocultando possíveis deficiências. Freud observa que o bebê é o suporte das projeções narcísicas dos pais, existindo para "indenizá-los" narcisiscamente, e afirma: "O amor dos pais, tão comovedor e no fundo tão infantil, nada mais é senão o narcisismo dos pais renascido, o qual, transformado em amor objetal, inequivocamente revela sua natureza anterior" (FREUD, 1914/1974, p. 108).

A criança, resgatando o narcisismo parental, pode surgir como uma possibilidade de rever feridas narcísicas destes, com uma função "reparadora". Assim, o filho, apesar de despertar temor nos pais ao expô-los novamente as suas questões infantis, representa também a esperança de enfrentá-las novamente e revê-las. Dessa forma, pensar na gestação e no nascimento de um filho convoca invariavelmente aspectos do narcisismo, tanto do pai quanto da mãe, suas lembranças e fantasias sobre suas primeiras relações.

No mesmo artigo, Freud revela como o nascimento de um filho reativa a criança que os pais um dia foram: o infantil dos pais. Destaca, assim, como o fator infantil permanece presente no psiquismo do adulto. Segundo Zornig (2008), o infantil corresponde à produção fantasmática do sujeito sobre sua infância. Para a autora, o conceito de infantil está referido a uma infância recalcada e, portanto, fundadora, já que é a partir da amnésia infantil que se constitui a história do sujeito. Ou seja, o infantil é aquilo que carregamos de marcas recalcadas do início de nossas vidas, e que forma o núcleo do psiquismo. O infantil tem início na vida de bebê, mas vai muito além da infância propriamente dita. Nesta ótica, o infantil não está referido a uma lógica cronológica, mas a um tempo de retroação subjetiva.

Nesta direção, já podemos entrever como antes do nascimento da criança os pais iniciam o percurso em caminho a parentalidade, a partir de sua própria história infantil. Dessa forma, contam com toda sua estrutura psíquica, imaginário, fantasias e histórias para iniciar as representações de seu futuro filho, e assim já preparam o terreno para a vinculação afetiva com ele. A transmissão consciente e 
inconsciente da história infantil dos pais, com seus conflitos e primeiras relações, já colore a representação da parentalidade desde muito antes do nascimento. SolisPonton e Lebovici (2004) apontam que para o pai e a mãe tornarem-se pais, é necessário um grande trabalho psíquico, que envolve um complexo processo de transmissão inter e transgeracional, o qual incluiria aspectos não somente dos pais, mas também dos avós, de aspectos socioculturais, mitos e conflitos a respeito da parentalidade.

Refletindo sobre a importante influência que as fantasias parentais, sonhos, medos, lembranças da própria infância e profecias sobre o futuro bebê, Lebovici (1987) propõe a existência de três tipos de representações dos bebês na organização psíquica dos pais: o bebê imaginário, o bebê fantasmático e o bebê real.

O bebê imaginário relaciona-se ao narcisismo parental e, portanto, é construído durante a gestação e diz respeito às projeções dos pais sobre o bebê, incluindo características imaginadas por eles, tais como traços, personalidade, sexo etc., sendo o bebê imaginário uma representação dos pais. Já o bebê fantasmático refere-se à história infantil de cada um dos pais, refletindo suas fantasias inconscientes e a forma como se organizaram edipicamente. Assim, os conflitos infantis dos pais e a relação estabelecida com seus próprios pais colorem a representação geral que eles têm acerca da parentalidade. Já o bebê real seria aquele que confronta os pais com sua alteridade e que se apresenta de forma mais efetiva a partir do nascimento. É o bebê que entra em interação com os pais e que tem suas próprias competências: é o bebê que os pais têm nos braços.

A partir das contribuições do autor, podemos supor que o nascimento de um filho é marcado por grande ambivalência, pois, ao mesmo tempo em que o contato com o bebê traz a possibilidade narcísica de reparar falhas na história parental, ele também reativa fantasmas edípicos e provoca uma ruptura no equilíbrio do casal (ZORNIG, 2012).

Nesse sentido, corroboramos as proposições de Stern (1997) de que o nascimento de um filho provoca uma neoformação psíquica nos pais, posto que sua inclusão no psiquismo parental produz mudanças profundas. $\mathrm{O}$ autor propõe que na gravidez ocorre uma reorganização do funcionamento psíquico da mulher, chamada por ele de constelação da maternidade - uma organização temporária que determinará novas fantasias, medos e desejos. Sua duração é variável, mas 
durante essa época ela se torna o eixo organizador para a vida psíquica da mãe, deixando de lado o complexo edípico como eixo organizador. A principal preocupação passa a ser o que Stern (1997) chama de "trilogia da maternidade" (p.161) referindo-se a preocupações e discursos que acontecem tanto interna como externamente concernente aos discursos da mãe com sua própria mãe, consigo mesma e com seu bebê. Tal constelação da maternidade provoca na mãe uma experiência de realinhamento, inaugurando uma zona psíquica diferente, na qual a nova tríade psíquica "mãe, mãe da mãe e bebê" (p.162) se torna eixo organizador central. Stern (1997) retrata esta constelação expondo seus temas centrais. O primeiro tema proposto pelo autor é vida-crescimento, relacionado à capacidade da mãe de manter a vida e o crescimento do bebê. A questão central aqui alude aos medos da mãe de fracasso em relação a vitalidade e desenvolvimento do bebê. O autor afirma que a situação mais perturbadora para a mãe é aquela em que não consegue planejar o curso do desenvolvimento de seu bebê, experimentando um vazio representacional. $\mathrm{O}$ segundo tema refere-se ao relacionar-se primário, diz respeito à capacidade materna de envolver-se emocionalmente com seu bebê. $\mathrm{O}$ terceiro tema é a matriz de apoio, ligado aos sistemas de apoio necessários para a mulher cumprir essas funções. E a última temática é a reorganização da identidade que, como indica, refere-se à necessidade da mãe de transformar e reorganizar sua identidade para permitir e facilitar essas funções. Essa reorganização é imprescindível e convoca a necessidade de modelos, assim a mãe revive a história de suas identificações com a própria mãe e com outras figuras parentais e maternais em busca dos modelos necessários.

Ainda pensando sobre as alterações psíquicas que ocorrem na gestação, Bydlowski (2002) destaca que ocorre uma modificação natural da vida psíquica das mulheres, surgindo um estado de permeabilidade entre as representações conscientes e inconscientes. Este estado é caracterizado por uma transparência, em que os fragmentos do pré-consciente e do inconsciente chegam facilmente à consciência. A autora sugere que esse estado se estabelece porque, na gravidez, o equilíbrio psíquico encontra-se abalado pelo duplo status do bebê: presente no interior do corpo da mãe e de suas representações, mas ausente de sua realidade visível. Dessa forma, as gestantes estabelecem, sem obstáculos, uma correlação entre a situação da gestação atual e as lembranças do seu passado, de modo que reminiscências antigas e fantasmas geralmente esquecidos surgem com força na 
memória, sem serem barradas pela censura. A força do recalque encontra-se “adormecida", não assegurando mais a proteção que habitualmente exercia.

A grávida diminui seu interesse pelo mundo exterior, mas, curiosamente, o bebê não ocupa predominantemente seu pensamento, pois ela permanece mais centrada em si própria. Nesse sentido, observamos como a gestante parece mais ligada à criança que ela foi (ou que acredita ter sido) do que à criança que ela carrega em seu ventre. Isso se faz compreensível pelo superinvestimento da história pessoal da mãe, característico desse estado. Bydlowski (2002) supõe que a gravidez inaugura um encontro íntimo da mulher consigo mesma devido à emersão de conteúdos psíquicos recalcados relativos a experiências e fantasias infantis.

Porém, essa modalidade particular de funcionamento, na qual as representações mentais estão centradas sobre uma forte polarização narcísica, não se mantém ao longo de toda a gestação. Conforme ressaltam Bydlowski e Golse (2002), a atenção da gestante que, de início estava dirigida para ela mesma, passa progressivamente a se dirigir para o futuro bebê, que começa a ter um estatuto de objeto no psiquismo materno. Isto significa dizer que o feto começa a apresentar um status exterior, embora ainda esteja no corpo de sua mãe. Após o nascimento, a partir da preocupação materna primária, a atenção psíquica da mulher se direciona ao bebê, mas a relação entre ambos se apoia nas projeções maternas ancoradas no bebê que a própria mãe foi.

A preocupação materna primária é um conceito winnicottiano que descreve clinicamente o período particular entre as semanas anteriores ao parto e as primeiras semanas após o nascimento do bebê, durante o qual a mãe é capaz de adaptar-se sensivelmente às necessidades de seu filho. Winnicott (1956/1978) indica que se trata de uma identificação regressiva da mãe com seu bebê que a possibilita captar os sinais do filho e interpretá-los com muita eficácia. A mãe que atingiu o estado de preocupação materna primária está plenamente devotada ao cuidado de seu bebê, o qual, de início, parece ser parte dela mesma. A partir de suas próprias experiências enquanto bebê, pode sentir o que o filho sente e, dessa forma, ela própria encontra-se num estado dependente e vulnerável. Nessa condição especial de sensibilidade exacerbada, a mãe se retrai para poder sentir-se no lugar do bebê. $\mathrm{O}$ autor compara esse período a uma dissociação, a um estado patológico, uma “doença normal”. 
Em relação ao estado de preocupação materna primária, Thomas Ogden (2010) corrobora a proposição winnicottiana, descrevendo esse processo como uma fuga ou uma dissociação, um estado sem sujeito. Tal condição teria que ser estabelecida para que a presença da mãe não fosse sentida como algo invasivo, preservando o continuar a ser do bebê. Nas palavras do autor:

Na preocupação materna primária, não existe algo como uma mãe. A mãe sente a si mesma no lugar do bebê e assim remove-se não apenas da experiência que o bebê tem dela, mas também, em grande medida, da experiência que ela tem de si própria. Esse estado é quase uma doença. (OGDEN, 2010, p. 122).

Este movimento de anular-se enquanto sujeito em prol de uma identificação com o bebê nos sugere um momento inicial de indiferenciação mãebebê. No entanto, Ogden (1996) afirma que, para se colocar no lugar do bebê e poder afinar-se com suas necessidades, a mãe deve vivenciar as necessidades do bebê como próprias mas, ao mesmo tempo, precisa manter um senso suficiente de sua própria subjetividade, distinta, para poder decodificar a experiência do bebê. A mãe sente sua alteridade, sente que seus desejos apontam para outra direção, no entanto não os considera. Segundo o autor, a mãe é uma presença invisível, mas sentida. Nesta perspectiva, durante a gestação ocorrem tensões progressivas entre mãe e bebê, evocando as questões de unidade e separação, de internalidade e externalidade.

A introdução desses conceitos sobre a transparência psíquica e a preocupação materna primária é importante para pensarmos o que ocorre no psiquismo materno em relação à forma como o filho é representado. De início, quando a mulher é tomada pela transparência psíquica, as representações maternas dominam o cenário. O futuro bebê já possui uma relativa concretude, pois se desenvolve no corpo da mãe, mas permanece ainda como um objeto interior, responsável pela reativação da criança que a própria mãe foi. Com o início do desenvolvimento da preocupação materna primária, ainda no final da gestação, o feto começa a apresentar um status exterior, embora ainda esteja no corpo da mãe. Começa a haver uma passagem da atenção psíquica que estava dirigida para ela mesma para o feto e, assim, a mãe pode começar a objetificar o feto em seu psiquismo. Após o parto e algumas semanas após o nascimento, a atenção psíquica da mãe centra-se sobre o recém-nascido, mas a relação se estabelece graças à reativação da mãe enquanto, ela própria, bebê, ou seja, ainda sob forte 
influência do objeto interno. Somente mais tarde o bebê será investido como um verdadeiro objeto externo, ou seja, não mais como puro representante do objeto interno (BYDLOWSKI; GOLSE, 2002).

Bydlowski e Golse (2002) afirmam que a passagem do bebê enquanto objeto interno para o bebê investido como um verdadeiro objeto externo depende de um processo que nem sempre coincide com seu nascimento. A passagem para o reconhecimento de alteridade no bebê acontece gradualmente e, às vezes, só irá se completar após o nascimento (SANTOS E ZORNIG, 2014). O reconhecimento do bebê em sua alteridade é um processo que decorre da possibilidade do desinvestimento progressivo do objeto interno em prol do bebê enquanto externo à mãe. Nem sempre esse processo coincide com o nascimento do bebê, sendo comum algumas mães tentarem reter o objeto interno perdido, o bebê dos seus sonhos e devaneios, tendo dificuldades em olhar para o bebê que está em seu colo.

Para que este trabalho psíquico possa ser feito (reconhecimento do bebê enquanto objeto externo), é fundamental que a função paterna possa mediar a relação entre a mãe e o bebê, de forma a possibilitar o progressivo desinvestimento do objeto interno. Como o bebê se constitui como objeto externo para o pai desde a concepção, este pode encarnar mais facilmente a função de separação e de reconhecimento do bebê enquanto alteridade e em sua dimensão de sujeito. Se a função paterna, inicialmente, potencializa a função materna, sendo uma facilitadora da relação dual mãe-bebê, é igualmente necessário que esta função interrompa essa relação fusional que se produz e assegure, assim, a elaboração de um espaço próprio para o bebê enquanto sujeito. Cabe ressaltar que a função paterna pode ou não ser exercida pelo pai real, desde que marque a presença de um terceiro que aponte novas perspectivas para além do filho.

Além da função paterna, as próprias competências do bebê real poderão ajudar nesta tarefa de modificar as fantasias dos pais e ajudá-los a abandonar a representação metafórica do objeto interno (SANTOS E ZORNIG, 2014). Na medida em que o bebê não é um reservatório passivo dos cuidados parentais, suas respostas podem modelar o tipo de parentalidade que lhe é oferecida, propiciando novas formas de interação que vão além dos modelos identificatórios que os pais trazem de suas histórias individuais. Existem diversos estudos que demonstram como atitudes e comportamentos parentais variam em função das características próprias do bebê, tais como sexo, idade e nível de desenvolvimento psicomotor. 
Pensando sobre como o feto interage e influencia nas relações desde cedo, Cyrulnik (1995) afirma que, a partir das primeiras semanas de gravidez, ele já não é totalmente passivo e vai procurar no seu meio os suportes que lhe convierem. Através de pesquisas e experimentos, o autor demonstra a sensibilidade fetal a determinados acontecimentos sensoriais e afirma que o feto vê indistintamente, estimulado pelo brilho e pelo movimento. $\mathrm{O}$ olfato também estaria ativo, podendo sentir o perfume do líquido amniótico (do cheiro da mãe), assim como a audição. Tudo isso indica que as interações mãe-bebê, ainda no ventre materno, devem ser consideradas como uma troca recíproca, nas quais cada um é levado a responder ao outro. Desde cedo, o bebê está apto a dar sinais de sua presença pela interação e, assim, evidenciar sua dimensão subjetiva. No próximo tópico pensaremos na marca de alteridade que o bebê comporta, revelando ultrapassar os modelos identificatórios que os pais trazem de suas histórias individuais.

\title{
2.2 Bebê: entre o familiar e o estranho
}

\author{
Eu não sou eu nem sou o outro, \\ Sou qualquer coisa de intermédio \\ Mário de Sá Carneiro
}

Há uma tendência em associar o bebê durante a gravidez apenas a uma encarnação do narcisismo materno, pois nos acostumamos a pensar a gravidez predominantemente a partir deste ângulo. Porém, não podemos deixar de observar que, de início, o bebê se apresenta para a mãe como um estranho. As modificações no corpo da futura mãe, bem como a percepção do movimento fetal, são presenças claras que marcam essa alteridade. $\mathrm{O}$ feto aparece, pelo menos sensorialmente, como um ser distinto que pode, inclusive, ser visualizado.

Muitos recursos atuais nos permitem ter acesso ao "bebê de dentro": a biotecnologia aplicada à obstetrícia vem se desenvolvendo no sentido de fazer presente o que ainda está por vir, acessando a vida intrauterina. A partir da década de 1980 , a ultrassonografia ${ }^{1}$ tornou-se um exame de rotina durante a gestação.

\footnotetext{
${ }^{1}$ A ultrassonografia ou ecografia é um exame de imagem que utiliza eco do som na produção de imagem, e pode ser utilizado como ferramenta diagnóstica na Medicina. Os aparelhos de ecografia utilizados hoje em dia mostram imagens contínuas do feto se movendo intraútero, podendo ser interpretados pelo radiologista ou obstetra que realiza o exame.
} 
Assim, com a visualização do corpo do feto e do estabelecimento de sua saúde antes mesmo de seu nascimento, a gestação se torna mais concreta. A visão do bebê vivo dentro do corpo materno permite uma confirmação da competência da mulher como procriadora e, além disso, indica a possibilidade de coexistência entre mãe e feto. Poder visualizar a imagem do bebê, de formas cada vez mais nítidas, reforça a diferenciação mãe-bebê, pois, apesar da imagem ser do interior do corpo materno, ela não indica uma fusão, e sim um ser já com suas formas, separado pela placenta. Pelas imagens de ultrassom, os pais são confrontados com aspectos de um bebê real que se choca com as representações do bebê imaginado. Essa aproximação com o bebê real traz uma imagem estranha, que guarda um caráter misterioso (ARAGÃO, 2012).

Missonnier (2004) defende que a ultrassonografia representa uma potencial violência. Acredita que, para os futuros pais, ver a imagem do feto pode ser desestabilizante, seja por desvelar o interior do corpo da mulher, seja por se tratar de uma busca de possíveis anomalias. Se houver uma anomalia, uma ameaça de morte pesa sobre o feto e a busca se tornará potencialmente trágica. Expor o "bebê de dentro" sem reconhecer a violência desse exame pode configurar algo destrutivo para os pais e vir na contramão de uma sustentação da parentalidade.

Frente ao bebê de dentro que é revelado, Aragão (2012) pontua que o acompanhamento de mães durante a gestação permite observar uma construção progressiva, preparatória e antecipatória do reconhecimento da alteridade do bebê. Para que essa construção possa se consolidar, faz-se necessário um longo e contínuo trabalho psíquico. Nesta visão, a gestação seria o tempo em que se dá esse trabalho de preparação para a relação objetal e que deve possibilitar a construção de um espaço para o bebê, dentro da mulher (em seu psiquismo) e de sua vida. A autora pontua que, no tempo da gestação, deverá se realizar o trabalho de transformar o estrangeiro em familiar, atribuindo-lhe características ancoradas em sua própria história infantil.

Ainda segundo Aragão (2012), podemos pensar que o bebê mobiliza em nós as origens enigmáticas de nosso ser, e que, portanto, será suporte projetivo de uma "estranheza inquietante". Nas palavras da autora, "o bebê se apresenta como um estrangeiro, constituindo um enigma que ela não conhece, nem decifra" (2012, p. 36). Ou seja, o bebê é, antes de tudo, um objeto estranho, invasor de seu espaço 
narcísico e corporal. A mulher tem em seu ventre um bebê que ora representa o seu bebê ideal, ora um ser estranho. Nessa perspectiva, Missonnier (2004) indica haver uma bipolaridade entre o bebê-ameaça e o bebê-rei. Através dessa concepção observamos o quão ambivalente pode ser essa relação que se encontra paradoxalmente entre o familiar e o radicalmente estranho.

Pensando nessa dicotomia, Missonnier (2004b) propõe o conceito do funcionamento psíquico placentário como metáfora da matriz desse estranhamento. A placenta é constituída de células fetais e, portanto, do DNA materno e paterno, e é imprescindível à manutenção da gestação. Funciona como interface entre mãe e bebê, realizando a homeostase entre os corpos e garantindo a sobrevivência do feto, já que o organismo da mãe tende a interpretar a presença deste como a de um corpo estranho e invasor, do qual ela deve se defender.

Partindo de uma analogia do funcionamento placentário, Missonnier (2004b) propõe o conceito psicanalítico de funcionamento psíquico placentário. Através dessa analogia, sustenta que não podemos conceber o bebê como uma mera extensão narcísica da mãe, uma vez que, desde o início, atesta-se a presença do pai - seja através do desejo da mãe por ele ou através das representações maternas do pai. Sendo a placenta constituída de células tanto maternas quanto paternas, ela funciona como uma marca de que existe, desde o início, algo que escapa ao materno, que é próprio da alteridade e, portanto, revela a presença de um terceiro. Desde o início, como afirma o autor, existe a copresença das linhagens parentais na placenta, que representa o ninho narcísico parental, onde o bebê se enraíza. Neste contexto, a placenta ganha contornos de metáfora, sugerindo uma "promessa objetal" nessa matriz narcísica. Se biologicamente, a placenta, como envelope primitivo, marca desde o princípio as linhagens parentais, psiquicamente podemos pensar, com o autor, que essa base forma o enquadramento narcísico do bebê, uma vez que a placenta psíquica revela um terceiro mediador da relação, esboçando o começo de um processo de individuação fetal desde o período pré-natal.

O que nos parece essencial ressaltar na metáfora placentária é que, tanto no plano biológico quanto no plano psíquico, a placenta configura um terceiro. Pensando em termos de circulação sanguínea, é a placenta que se posiciona como uma interface entre o sistema materno e o sistema fetal. Quanto ao aspecto psíquico, a placenta sugere que o encontro das duas psiques parentais vai 
constituir outra representação da qual a criança vai psiquicamente advir. Então, podemos inferir que não há relação simplesmente dual. Dessa forma, a ideia do funcionamento psíquico placentário protege a mãe (e também o bebê) de fantasias de fusão e de destruição, já que cria um espaço entre mãe e bebê, facilitando o processo de diferenciação. Missonnier (2004), em seu trabalho com gestantes, acredita que essa ideia tranquiliza as mães, uma vez que sugere que seus bebês não sentem tudo o que ela experimenta. Solis-Ponton (2004) ressalta que esta ideia é muito útil no acompanhamento das gestantes, pois permite que uma mãe angustiada compreenda que há um terceiro protetor, uma barreira que é, ao mesmo tempo, princípio de diferenciação.

A partir do que estamos refletindo, é relevante notar que o conhecimento progressivo do bebê real e a presença inerente de um terceiro que aponta um princípio de diferenciação mãe-bebê desde o início nos impossibilita considerar o bebê de dentro somente como uma extensão psíquica da mãe. Missonnier (2004) afirma que, por haver uma elaboração objetal progressiva no feto, não se pode supor apenas um aprisionamento narcísico. $\mathrm{O}$ autor acredita que essa ideia pode ser fruto de um erro de ponto de vista de clínicos que atendem pacientes graves com dificuldades significativas no início objetal.

Na mesma direção, Zornig (2010) pontua que as mudanças ocorrem não apenas em função das projeções e representações parentais sobre o bebê, mas em função da mudança que a presença real do bebê provoca nas interações entre eles e seus pais. Apenas o reconhecimento do filho em sua diferença permite aos pais construir uma relação com a marca do novo e da criatividade, indo além de uma repetição do passado. Normalmente, na saúde psíquica, as mulheres têm antecipações criadoras da alteridade do bebê por vir. E assim, durante os meses da espera pelo bebê, supõe-se que a mãe possa progressivamente construir um espaço psíquico para o bebê. O tempo cronológico da gravidez é necessário para permitir a elaboração do bebê como tal. Conforme as questões que estamos abordando, ao longo desses meses de espera vai ocorrendo um deslizamento da percepção do feto como parte do corpo da mãe até se constituir como um outro, marcado pela alteridade.

Refletindo sobre essa construção materna, Stern (1997) observa que ao feto são paulatinamente atribuídos traços físicos, características de personalidade, de temperamento, e tanto mais quanto a criatividade e devaneios maternos 
permitirem. Este movimento geralmente ganha força a partir dos quatro meses, quando o feto começa a ser mais sentido e suas manifestações de vida tornam sua existência mais palpável. Nesta época, existe um acréscimo na riqueza e na especificidade das representações maternas acerca de seu bebê. Após os sete meses, entretanto, quando atingem seu ápice, as representações acerca do bebê imaginadas pela gestante geralmente diminuem. O autor acredita que isso ocorre como uma forma de proteger o bebê que está para nascer e a própria mãe de uma frustração decorrente da discordância entre o bebê de sua representação e o bebê real. Para Stern, "as mães intuitivamente protegem seu bebê que está por chegar e a si mesmas de uma potencial discordância entre o bebê real e um bebê representado de forma excessivamente específica" (1997, p. 28). As representações acerca do bebê têm de ser reconstruídas, agora a partir das linhas gerais oferecidas pelo bebê real.

Esse cenário psíquico envolve o devaneio materno em torno da criança imaginada e essas construções criativas constituem um espaço de antecipação do filho, importante para a percepção da individualidade da criança. Aragão pontua que:

Entre a passagem de uma continência interna para uma continência externa há,
para cada gestante, um ponto de equilíbrio que se situa entre a fantasia materna
antecipatória e estruturante e esse momento de risco do primeiro encontro com
um desconhecido. A maneira como se deram esses processos de construção
antecipatória, quais negociações foram possíveis para mãe, entre a idealização
narcísica da criança por vir, os efeitos do ressurgimento das angustias infantis
recalcadas e a ambivalência fundamental inerente a toda relação com outro são
todos fatores que marcarão o "bebê de fora", em sua dialética com a
representação do bebê de dentro. (2012, p. 79$)$

Esse momento leva a mulher a desenvolver um trabalho psíquico complexo, ao mesmo tempo narcísico e objetal. O feto não é ainda um objeto interno, nem um objeto externo. Veremos a seguir que, por suas particularidades, pode ser considerado um objeto virtual e funciona como operador simbólico entre a realidade e a fantasia. A mãe se confronta com um duplo movimento: por um lado, exerce uma busca imaginária pela criança que ela mesma foi e, por outro, busca construir uma identidade parental. Essas identificações, como realça Aragão, "relançam sobre a cena psíquica os cenários de fusão, de separação e de diferenciação" (2012, p. 81). 


\subsection{Virtualidade: o bebê enquanto promessa}

Percebemos até o momento como a relação da mãe com seu bebê ainda no ventre é peculiar, estabelecida antes de o bebê se configurar como um objeto em si mesmo, completamente externo à mãe. Por essa particularidade, dizemos que o feto, no útero materno, ainda não configura um objeto real. Aragão (2012) nos alerta para o duplo status do bebê durante a gravidez: ele está presente no interior do corpo da mãe e em seus pensamentos conscientes e inconscientes, mas ausente da realidade visível. Dessa forma, só pode ser objeto de interações fantasmáticas, onde o que está em jogo são essencialmente os conteúdos psíquicos maternos e paternos, em torno desse objeto ainda eminentemente narcísico que é o bebê, já que o "bebê existe, sem existir" (p. 41).

Conforme nossa reflexão, a gravidez constitui um período em que se desenvolve um trabalho de preparação da relação objetal, marcado por uma dinâmica dupla, tanto narcísica como objetal. Nesse sentido, Missonnier (2004) elabora o conceito de objeto virtual, que nos auxilia a desenvolver essa questão, pois destaca a característica intermediária entre o feto como objeto internalizado (que ainda não é real), mas ao mesmo tempo em que já aponta a possibilidade de ser. Pensando em como o feto representa para os pais a promessa da criança que virá, o autor destaca a virtualidade da relação que se estabelece entre eles. Assim, propõe a noção de relação de objeto virtual para referir-se ao modo particular de relação entre a mãe e o bebê em seu ventre, descrevendo-a como um processo dinâmico e adaptativo que envolve comportamentos, afetos e representações em torno do feto.

A criança virtual ancora-se, em parte, nas crianças do imaginário parental, descritas por Lebovici (REF citado por MISSONNIER, 2004), mas não se reduz a essas representações, projeções, expectativas e sonhos dos pais. A virtualidade é também atravessada por algo do bebê que, aos poucos, dá sinais do que lhe é próprio. Vimos no tópico anterior como o avanço tecnológico na área da obstetrícia vem possibilitando a observação do embrião e do feto em vários ângulos, possibilitando um "conhecimento" do bebê que está sendo gestado. No que se refere a essas tecnologias, Missonnier (2004) pontua, no entanto, que a medicina faz uma previsão, e não uma antecipação. Através da ecografia, o ultrassonografista poderá fazer uma previsão de possíveis patologias, formação 
dos órgãos, estimativa do tamanho e do peso do bebê, da condição da placenta... enfim, poderá fornecer alguns dados importantes sobre o bebê. Mas trata-se sempre de uma previsão. O bebê/feto permanecerá com a marca da virtualidade, posto que ainda não é um bebê eminentemente real, apesar de toda visualização pré-parto.

O objeto virtual (futuro bebê) está presente enquanto potência, pois todas as indicações apontam para a confirmação de sua existência, mas ainda não é atual. $\mathrm{O}$ autor exemplifica essa condição trazendo a ideia da semente e da árvore. Uma semente traz a ideia de uma árvore, ela representa uma possível árvore, podemos apenas pensar que nascerá uma árvore e como ela será. Já a árvore é de fato a atualização da semente. Nesse sentido, a relação que se estabelece intraútero entre mãe e bebê será sempre baseada em uma virtualidade. O sonho materno da criança imaginada será como uma antecipação do filho, ainda virtual. Seguindo o pensamento de Missonnier (2004), a relação de objeto virtual representa a matriz de todo o desenrolar posterior da relação de objeto, num processo que se inicia por um investimento narcísico extremo e vai se desenvolvendo até a emergência progressiva de um investimento pré-objetal.

Ainda segundo o autor, uma crescente procura clínica ilustra quantos cenários comportamentais afetivos e fantasmáticos imaginados durante a gravidez organizam parcialmente as relações posteriores com o bebê no pós-natal, mostrando como a relação com esse objeto virtual é importante. Contudo, o autor alerta que seria um erro considerar a criança virtual apenas como uma encarnação do narcisismo parental. A relação de objeto virtual considera que há uma constante interação entre o embrião/feto e seu meio (constituído principalmente pela vida psíquica parental).

Retomando o que vimos até agora, a alteridade da criança que é gestada é progressivamente mostrada. Durante as consultas pré-natais, algo próprio do bebê se revela e influencia a projeção de uma virtualização, o que poderá ser organizador ou nocivo para a relação com o bebê. Quando a imagem que os pais possuem dos seus filhos encontra na ecografia uma confirmação, ela poderá servir como suporte para a antecipação de seu bebê como objeto, e isso representará algo positivo para a construção da parentalidade. No entanto, quando o que é revelado pelo saber médico é algo que não vem ao encontro da criança imaginada pelos 
pais, isso poderá ter um efeito negativo no impulso criativo destes, no sentido de dificultar o acréscimo de algo de suas histórias ao que foi revelado.

No que diz respeito ao objeto virtual de Missonnier, pensamos ser possível estabelecer uma associação com o conceito winnicottiano de objeto transicional, uma vez que o virtual, conforme postulado por Missonnier (2004), estaria em uma área intermediária de experiência, para a qual contribuem tanto a realidade interna quanto a vida externa.

Winnicott (1951/1975) define os fenômenos transicionais como uma área de repouso em que não é preciso manter separadas as realidades interna e externa, onde o teste de realidade não é convocado. O objeto transicional representa a transição do bebê de um estado em que este está fundido com a mãe para um estado em que está em relação com ela como algo externo e separado. O autor desenvolveu a ideia de um espaço intermediário entre o subjetivo e o objetivo, no qual se localizaria a experiência criativa. Esta visão refere-se a um espaço que não é dentro nem fora, e que assinala que o objeto deve se apresentar para, paradoxalmente, ser criado. Segundo o autor:

Os objetos transicionais e os fenômenos transicionais pertencem ao domínio da ilusão que está na base do início da experiência. Este primeiro estágio de desenvolvimento é tornado possível pela capacidade especial, por parte da mãe, de efetuar adaptações às necessidades de seu bebê, permitindo-lhe assim a ilusão de que aquilo que ele cria existe realmente. (WINNICOTT, 1951/1975, p. 30)

Pensamos que o virtual, conforme postulado por Missonnier (2004), coincide justamente com essa área intermediária de experiência para a qual contribuem tanto a realidade interna quanto a vida externa. Na relação com o objeto ainda virtual, os pais podem experimentar algo como u ma ilusão, entre o subjetivo e aquilo que é objetivamente percebido. Podem criar, fantasiar e construir representações do filho que gestam, ou seja, podem experimentar um processo desde o puramente subjetivo até a objetividade. A relação com o objeto virtual representa um processo de transição em direção à "libertação" de um tipo narcísico de relação de objeto, da mesma forma como o objeto transicional instaura um movimento que irá permitir a gradual separação da mãe.

Tal qual o objeto transicional deverá se tornar gradativamente descatexizado, a relação com o objeto virtual também será aos poucos desinvestida em prol de um investimento no bebê real. Pensamos que seria 
bastante prejudicial não conseguir viver uma relação com um bebê projetado virtualmente, tanto como não se desprender dessa virtualidade ao final da gestação.

Até esse momento, refletimos sobre o que acontece em relação à gravidez. Essa discussão visava alcançar uma melhor compreensão da representação do feto para seus pais, para podermos, então, refletir o que se passa quando a morte interrompe esse já conturbado momento de espera pelo bebê. Na morte fetal, o que morre não é apenas o bebê real, mas perde-se uma relação com o objeto virtual, que deveria ser gradualmente desinvestida com auxílio da presença real do filho, mas que neste caso não ocorrerá. Passaremos então, agora, às considerações sobre o óbito fetal e sobre as dificuldades inerentes ao trabalho que deverá se seguir. 


\title{
3. Quando a morte interrompe o processo
}

\author{
Oh, pedaço de mim \\ Oh, metade arrancada de mim \\ Leva o vulto teu \\ Que a saudade é o revés de um parto \\ A saudade é arrumar o quarto \\ Do filho que já morreu \\ Chico Buarque, Pedaço de mim
}

Após fazermos uma reflexão inicial sobre o que ocorre usualmente no psiquismo dos pais, especialmente da mãe, durante o processo de tornarem-se pais, voltemo-nos agora a pensar o que ocorre quando esse já delicado processo é interrompido pela morte do bebê. A morte do bebê ocorre justamente no momento em que muitas outras questões, como abordamos no capítulo anterior, foram convocadas e procuram um novo equilíbrio.

\subsection{Vida e morte sobrepostas}

A representação que temos da nossa existência é que nascemos, envelhecemos e morremos. Contudo, essa lógica é, às vezes, totalmente inversa, como podemos observar diante das expressivas taxas de mortalidade fetal, as quais apontam que cerca de uma em cada cinco gestantes passam pela experiência da perda embrionária ou fetal (BRASIL, 2012). Bebês ainda no útero materno podem sofrer uma interrupção dos seus impulsos de vida, lançando seus pais na incompreensão. No momento em que os pais se preparavam para dar a vida, a criança que é esperada e sonhada desaparece, antes mesmo de conhecer o mundo, de conhecer seus pais. Assim, os pais perdem não apenas um ser amado, mas, sobretudo, o que potencialmente o filho poderia ter lhes dado, se tivesse vivido.

A gravidez, usualmente vista como um momento de criação de vida, de construção de devaneios e de muitas expectativas, torna-se, assim, um cenário sombrio e desconhecido. A morte invade as maternidades e espaços onde não costuma, normalmente, ser pensada, tornando, a nosso ver, ainda mais difícil que essas famílias consigam lhe atribuir um lugar na realidade e em seus pensamentos. Dessa forma, parece-nos inevitável que a morte fetal vá exigir um trabalho de elaboração psíquica bastante singular, pois a representação do bebê que não nasceu vivo certamente apresentará dificuldades de se encaixar nas representações 
usuais. Para Soubieux (2014), “A conivência entre a vida e a morte, apressando a ordem das gerações, ocorrendo na fragilidade da gravidez, incrustada na carne machucada da mãe, questiona as representações parentais do bebê que não viveu" 2 (p. 22).

A morte de um filho é geralmente vista como um dos mais dolorosos acontecimentos que podem ocorrer a uma pessoa. No entanto, quando falamos em perdas de bebês intraútero, observamos certas particularidades. A rede social que cerca os pais que sofreram a perda tem dificuldades de compreender a dor que estão sentindo, pois, para eles, é como se o bebê nunca tivesse existido. Espera-se um período de tristeza, mas normalmente não se atribui o mesmo status atribuído à morte de um filho conhecido socialmente. Usualmente escutamos frases como "O tempo vai curar", "Vocês ainda são novos, poderão ter outros filhos", "A vida continua", "Foi melhor assim". Frases como essas mostram como a tendência social gira em torno de uma subestimação ou descaracterização do fato. Quando um bebê morre antes de vir ao mundo, na maioria das vezes, é como se não tivesse tido um acontecimento para a sociedade - "a criança não nasceu, portanto, ela não existe”. É frequente que, em nossa cultura, a intensidade de um vínculo seja associada ao tempo de relacionamento (IACONELLI, 2007). Dessa forma, a identificação de quem sofreu a perda com o objeto perdido pode ser desconsiderada nos casos de perda fetal.

O corpo da mulher evidencia as marcas da gravidez, muitas vezes até a produção de leite é iniciada. No entanto, há uma tendência a escamotear o real significado desta morte, como se não se tratasse mesmo da morte de um filho. Apesar da mobilização crescente de associações de pais que sofreram perdas, especialmente grupos na internet, e um maior envolvimento de profissionais sensíveis a esta temática, permanece ainda uma grande indiferença em nossa sociedade relacionada à morte desses bebês que não nasceram vivos - e essa costuma ser uma queixa comum entre as famílias enlutadas, pois se sentem incompreendidos em sua dor e, muitas vezes, são levados a um isolamento.

Refletimos sobre a mensagem ambígua e confusa que é passada para esses pais, ao observarmos que, nas sociedades ocidentais, assistimos a um grande paradoxo. Por um lado, os bebês são atualmente o centro de toda atenção, vistos

\footnotetext{
${ }^{2}$ Tradução nossa.
} 
como "Sua majestade, o bebê", enaltecidos em revistas, livros e cinema. São realizados muitos investimentos em medicina fetal e reprodutiva, pensa-se em cada vez mais formas de possibilitar a fertilização em condições adversas. No entanto, ao mesmo tempo, quando o bebê, que era até então extremamente valorizado, morre, há uma forte e súbita tentativa de reduzir sua importância, contribuindo para que essa morte permaneça como um tabu (Soubieux, 2008). O entorno considera a morte do bebê como uma espécie de fracasso, fazendo com que retornem a uma lógica medieval, na qual era comum a ocorrência de muitas gravidezes, já que apenas algumas crianças “vingavam”. Tal lógica nos parece muito penosa para as famílias, já que o lugar ocupado pela criança em nossa sociedade é totalmente diferente atualmente. Mesmo considerando a realidade de regiões do Brasil em que os índices de mortalidade infantil ainda permanecem altos (por mais que tenham diminuído nos últimos anos), não podemos deixar de notar que a criança é estimada como um sujeito que ocupa papel central nos dias atuais e esforçar-se para escamotear o valor de sua existência, e de sua perda, afigura uma incoerência.

O não reconhecimento por parte do entorno poderá ser bastante prejudicial aos psiquismos desses pais, podendo, inclusive, influenciar para uma resposta patológica frente à morte do filho. Essa morte convoca um luto singular que demanda, por sua vez, uma reflexão particular, conforme procuramos sustentar nesta dissertação.

Casellato (2005) destaca que vivemos em uma sociedade na qual a relação com a morte é marcada por evitação e negação. Como resultado, observamos muitas situações em que não há o reconhecimento social de determinadas perdas, o que dificulta a expressão dos sentimentos e a participação dos rituais (participação no sepultamento e cerimônias de despedidas), podendo configurar um obstáculo à instauração do processo de luto. Notamos que é o que frequentemente ocorre nos casos de óbito fetal, sendo questionado pela autora se este poderia ser considerado como um luto silencioso, pontuando a dificuldade de se dividir questões relacionadas à perda fetal com outras pessoas, ou como um luto silenciado, enfatizando a pressão social que é feita para uma rápida recuperação e retomada das atividades rotineiras.

Binotto (2005) fala que, diante de uma perda fetal, o silêncio sobre a morte sugere um forte sinal do ato de escamoteação a que todos são convidados. 
Entendemos essa afirmação da autora, e a corroboramos com nossas observações empíricas na clínica perinatal, pela frequência com que familiares e pessoas próximas envolvidas tendem a tentar continuar suas vidas como se nada tivesse acontecido. Parece haver uma forte tentativa no sentido de destituir essa perda de significado e retirar os traços que possam ter deixado.

Através de nossa prática em maternidade, observamos que, rotineiramente, uma das primeiras práticas de cuidado após o nascimento de um natimorto ${ }^{3}$ é procurar impedir a descida do leite materno. Os médicos prescrevem o quanto antes uma medicação que inibe a produção e a equipe de enfermagem costuma enfaixar o seio da mulher para que a pressão e a falta de estímulo de sucção sinalize ao corpo que o leite não será necessário. O leite materno supõe a presença de um bebê, e produzi-lo sem um filho para usufruir expõe a falta de forma indisfarçável. Nesse sentido, acreditamos que a pressa em interromper a produção do leite materno é tão grande, tendo em vista que é algo concreto e real que marca que ali havia uma vida.

Diante de um óbito dessa natureza, equipe de saúde, família e amigos, muitas vezes, tendem a desvalorizar o sofrimento dos pais, especialmente da mãe, procurando privá-los de entender, sofrer e elaborar o luto. Destacamos a mãe em especial, por se tratar de algo que ocorre em seu corpo, sendo comum que o entorno procure preservá-la de forma mais incisiva. Muitas vezes, ao pai cabe resolver trâmites legais, referentes ao atestado de óbito e a questões relacionadas ao sepultamento, mas raramente a mãe se envolve nesses aspectos.

Klaus e Kennell (1992) afirmam que, quando um bebê morre, geralmente elimina-se rapidamente qualquer evidência da morte, o que torna a comprovação da morte ainda mais árdua de ser reconhecida e elaborada. Raramente instituições hospitalares oferecem práticas que possibilitem que pais e familiares possam se expressar e vivenciar livremente os sentimentos de luto. Não se costuma incentivar os pais a verem o natimorto, nem mesmo a falar sobre o que aconteceu.

Normalmente, após um óbito fetal, os pais podem contar com poucas recordações do filho, provocando com frequência uma sensação de irrealidade e vazio. Também observamos ser comum que outros familiares desmanchem o quarto do bebê e se desfaçam de pertences que já tinham sido adquiridos. Dessa

\footnotetext{
${ }^{3}$ Denominação dada ao feto que morreu dentro do útero ou durante o parto.
} 
forma, os pais (especialmente a mãe), são privados de um importante ritual, possivelmente aumentando ainda mais a solidão experimentada. Há um temor dos pais - e desejo do entorno - de que os poucos traços que o bebê deixou possam ser apagados.

\subsubsection{O impacto do óbito fetal na família}

A dificuldade em lidar com o óbito fetal afeta a todos os envolvidos, especialmente a mãe, o pai, o casal e, quando existem, irmãos e avós. Os pais são atingidos no mais íntimo de si mesmos e, por vezes, também em sua vida como casal. Para Soubieux (2008), o projeto de ter um filho permite ao casal se projetar no futuro e sonhar com uma nova vida. Dentro deste enquadre, o óbito fetal é vivenciado como uma interrupção traumática de uma projeção que exige, de cada um deles, um trabalho de elaboração da perda. Cada cônjuge irá reagir de acordo com sua estrutura psíquica e suas próprias experiências de separação e perda, mas certamente a história pregressa do casal, os laços particulares que os une e os acontecimentos da vida conjugal também influenciarão a maneira pela qual atravessarão esse acontecimento.

A autora enfatiza que a temporalidade não é a mesma para cada um e ressalta que o tempo da mãe costuma ser mais lento. Afirma também que, por questões socioculturais, há uma tendência de alguns homens a não falar sobre seu sofrimento por medo de despertar ainda mais tristeza em suas companheiras, as quais, por sua vez, sentem-se mais solitárias por interpretarem o silêncio como uma insensibilidade. O risco eminente é de se criar um abismo entre eles e que essa lacuna possa colocar forte pressão sobre o casal. A forma como cada um poderá iniciar o trabalho de luto, ou mesmo não iniciá-lo, também influenciará na forma de convivência do casal.

Soubieux (2008) relata, de acordo com sua prática clínica, que alguns casais se separam após a morte do bebê, outros permanecem juntos só até conseguirem ter outro bebê e então se separam, e que há ainda os casais que se fortalecem diante dessa experiência e surpreendem-se com a capacidade de criar uma nova relação entre eles. Segundo a autora, o futuro do casal vai depender do que cada um pode compreender e tolerar do sofrimento do outro. A dor, quando pode ser compartilhada, ajuda os casais a se reencontrar, a entender melhor um ao 
outro, a aceitar e respeitar suas diferenças nas formas de viver e a superar esse drama. Reconhecemos, por conseguinte, que as possibilidades de formas de enfrentamento de cada casal frente a esta perda são inúmeras e refletem suas próprias organizações internas e externas. Trazemos agora um caso de uma mulher que sofreu uma perda gestacional aos oito meses de gravidez para nos auxiliar na compreensão do quão delicado pode ser a travessia por essa experiência.

Ana ${ }^{4}$ procurou um acompanhamento psicoterápico individual meses depois da perda sem, no entanto, relacionar essa busca de ajuda à morte da futura filha. Acreditava que tinha aceitado essa perda, pois voltara ao trabalho logo em seguida e vinha conseguindo realizar seus compromissos. Contudo, sentia-se diferente e mais distante de seus familiares, mesmo do marido, com quem não tinha mais relações sexuais e nem sentia prazer em passear junto.

Ana contou que pediu para amigas próximas no trabalho que orientassem os demais a não tocar no assunto da filha com ela. Falou que, sem saber bem como, se estabeleceu um "pacto do silêncio" sobre o assunto e que não falava sobre a filha nem com familiares próximos nem com seu marido. E diz que, de verdade, praticamente não pensava mais sobre isso, "queria continuar a viver como se nada tivesse acontecido". Às vezes, sentia como se tudo tivesse sido um sonho. Disse que todas as roupinhas que havia comprado sumiram. O quarto rosa foi pintado de bege. Lembrava-se de roupas que havia comprado, de enfeites para o quarto, do quanto havia pesquisado sobre o carrinho ideal, da quantidade de fraldas que havia ganhado, tudo subitamente apagado. Em terapia, após muito trabalho e muitas lágrimas, não conseguia compreender como tinha ficado calada diante de tamanha violência - na verdade, questionava-se como jamais tinha pensado nisso como uma violência.

Tal como aconteceu com Ana, é frequente que amigos e familiares não falem sobre a perda e acabem por pressionar essas mulheres a retomarem sua vida muito rapidamente. As próprias leis trabalhistas corroboram essa urgência a voltar “a vida normal”, pois não há uma regulação específica para licença após uma perda fetal. É frequente que os obstetras concedam à mulher uma licença médica

\footnotetext{
${ }^{4}$ Em respeito à ética profissional, utilizamos nomes fictícios e alteramos alguns dados nesta e nas demais vinhetas clínicas apresentadas nesta dissertação, a fim de proteger, por meio da confidencialidade, a identidade das pessoas envolvidas.
} 
de, no máximo, duas semanas. Para os homens, não há regulamentação prevista por lei, sendo consideradas apenas as questões ideológicas de cada empresa. Pais e mães não dispõem de espaços, nem de tempo, para dividir efetivamente sua dor pelo seu bebê morto, já que, para a maioria, ele nem chegou a existir. Para Braga e Morsch (2003), é difícil que a rede de apoio enxergue o bebê como um sujeito possuidor de uma história e, por isso, não atribui uma dimensão maior a sua perda. É muito comum que pais que sofreram perdas fetais sejam confrontados com frases de pessoas próximas que pretendem mostrar como seria pior "perder um filho mais velho".

O bebê, tão valorizado em nossa cultura, normalmente é anunciado e aguardado por toda a família, desde o início da descoberta da gravidez. Quando existem outros filhos, é bastante doloroso e confuso viver a morte de um irmão nesse período. Em função da idade, da maturidade, da vida pregressa social e cultural, cada irmão terá uma visão diferente sobre a morte, lidando com ela de maneira singular. No entanto, é comum que não consigam compreender o que está ocorrendo, nem mesmo entendam seus próprios sentimentos. Os pais estão extremamente fragilizados e podem ter dificuldade em dar uma explicação para sua tristeza, o que os desorganiza bastante. As ideias que surgem sobre a morte do bebê podem ser devastadoras para o irmão, e normalmente são mais dolorosas do que a realidade.

Lembramo-nos de uma paciente que, após sofrer um aborto espontâneo com 33 semanas de gestação, contou ao filho de quatro anos que "infelizmente, tinham perdido o irmãozinho". Com o tempo, o filho começou a apresentar muitas alterações de comportamento e certa agressividade direcionada, especialmente, à mãe. Em um dia de chuva ao sair para a rua, sua mãe pediu para que tomasse cuidado para não perder a capa de chuva. O menino, indignado, disse que se perdesse alguma coisa não faria como ela, que perdeu o irmão dele e "nem foi procurar". Através dessa pequena passagem, podemos inferir o quanto é importante ajudar as crianças (também) a colocar seus sentimentos em palavras e assim auxiliá-los a elaborar o acontecido. Na tentativa genuína de poupar seus filhos de seu sofrimento, os pais, muitas vezes, se afastam deles e seu silêncio, somado à tristeza evidente, até para crianças ainda muito pequenas, pode ter um efeito perigoso. 
Outras vezes, são os filhos que, procurando proteger seus pais abalados pela dor, dissimulam suas próprias emoções e suas dificuldades em lidar com a perda. Os pais, tomados por sua própria dor, podem estar menos atentos e disponíveis para os outros filhos e, por vezes, não percebem esse embotamento, achando que os filhos estão "reagindo bem" ou que ainda não possuem capacidade para compreender o que aconteceu. De fato, esses filhos permitem ser esquecidos, como Soubieux (2008) afirma, pois se sentem impotentes e insuficientes para fazerem seus pais felizes de novo. Outra reação comum nas crianças, apontada pela autora, é a criança que, diante da tristeza angustiante da mãe, passa a lhe solicitar muito para desviar-lhe de seus pensamentos sombrios e lhe fazer reagir.

Para Soubieux (2008), entender o que os irmãos sentiam pelo bebê ao longo da gestação é importante para compreender o que essas crianças experimentam após a morte do irmão esperado. Habitualmente, uma forte ambivalência toma conta dos mais velhos quando descobrem que a mãe está grávida. Ao mesmo tempo em que podem desejar ter um irmão, desejam guardar seu lugar especial junto aos pais. Esse futuro bebê, que cresce visivelmente na barriga da mãe, pode representar um rival.

Em efeito, esse futuro bebê que monopoliza cada vez mais atenção de todos, representa uma falta e surge como um perigoso rival. Ele teme perder o amor dos pais. Além disso, ele compreende que agora ele não é mais o centro de interesse. Alguma coisa mudou na casa, uma nova cumplicidade se instalou entre os pais em torno de um acontecimento que ele não pode materializar e que ele se sente excluído, mesmo que tentem lhe fazer participar. A onipotência infantil é, então, atacada e danificada. (SOUBIEUX, 2008 p. 133, tradução nossa)

Freud, no caso do pequeno Hans (1909/1974), diante da hostilidade que o menino experimentava pela irmã recém-nascida também constatou a ameaça de perda de amor que o novo irmão pode incutir, assinalando inclusive que pode adquirir um efeito traumático. A criança não é mais o centro do mundo, é invadida pela inveja e pelo ódio a este intruso que a expulsa da posição que acha que tem no amor dos pais. Freud observava como a vinda de um rival ao mundo constitui uma ameaça à supremacia do primogênito, suscitando também ressentimentos contra a mãe por ter lhe imposto os irmãos. 
Privados de explicações coerentes e tendo experimentado pensamentos hostis em relação ao irmão durante sua espera, correm o risco de elaborar suas próprias interpretações para a morte do bebê de forma bastante angustiante e, normalmente, mais severa do que a realidade. A criança pode se culpabilizar pelo desaparecimento do bebê e acreditar que seus pensamentos ruins sobre ele podem, magicamente, ter levado à morte do "rival". A culpa, apesar de ilógica, provém da realização inconsciente do desejo de morte do irmão. Para Klaus e Kennell (1992), uma das melhores indicações da evolução sadia do luto, nos pais, seria a capacidade para discutir e sentir a perda junto aos demais filhos. Ocupar-se dos mais velhos pode ajudar os pais a retomar os hábitos cotidianos e a elaborar novos projetos.

Nos casos em que se instala uma depressão materna após uma perda fetal, a criança pode ser lançada num estado muito delicado. A tristeza da mãe e a diminuição súbita de seu interesse por ela provocam uma mutação abrupta da imago materna. A mãe pode estar presente fisicamente, mas ausente psiquicamente, o que é extremamente violento para a criança, pois, além da perda do amor da mãe, há uma perda de sentido. Nesse caso, a criança não conta com nenhuma explicação para compreender o que se passa. Num primeiro momento, a criança pode tentar reparar a mãe, lutar contra a angústia da perda do amor, seja pela agitação ou solicitação frequente. Quando esses meios não são eficazes, a criança pode desinvestir do objeto materno e se identificar de maneira inconsciente com a mãe deprimida. É possível pensarmos uma aproximação entre o conceito clínico de Green (1980/1988) acerca do complexo da mãe morta e a possível vivência de crianças que tem que lidar com a depressão materna diante do óbito fetal do irmão.

Segundo Green (1980/1988), o complexo da mãe morta tem como característica essencial uma depressão na criança pela ausência da mãe, contudo a mãe não se abstém da realidade. A depressão tem lugar na presença do objeto mãe, mas ela própria deprimida, absorvida por uma privação ou abandono. O autor aponta que um dos principais fatores precipitantes dessa depressão materna seria a perda de uma pessoa cara a ela, como a morte de um filho. E ainda destaca que: 
O caso mais sério é a morte de uma criança em uma precoce idade, como todos os autores compreenderam. Particularmente existe uma causa que se mantém oculta, em virtude de os sinais manifestos pelos quais a criança poderia reconhecê-la, e assim obter um conhecimento retrospectivo dela, não ser nunca possíveis porque estão em um segredo: uma falha da mãe. (GREEN, 1980/1988, p. 155)

O que se realiza, então, é uma mudança brutal na imago materna - uma transformação na vida psíquica ocorre no momento da privação da mãe quando abruptamente ela se desliga do seu filho. O filho experimenta esse desligamento como uma catástrofe, porque, sem qualquer sinal de alarme, o amor que ele tinha foi perdido. Isso representa um importante traumatismo narcísico para a criança, que é surpreendida não só com a perda de amor, como com a ausência de significado. A tristeza da mãe e a diminuição de seu interesse pelo filho que permanece vivo estão em primeiro plano.

Retomando a reflexão sobre o impacto nos envolvidos no óbito fetal, acreditamos também ser importante fazer uma breve consideração sobre a vivência dos avós. Os avós sofrem pelo sofrimento de seus filhos e, por não se tornarem avós, a filiação é interrompida por essa morte prematura. A inversão da ordem das gerações perturba toda a dinâmica transgeracional e os avós também são muito afetados, podendo se sentir desamparados. Às vezes, podem experimentar um forte sentimento de culpa, se sentindo implicados na doença do bebê, especialmente quando esta experiência de morte de um bebê se repete na família.

Szejer e Stewart (1997), atentos às "coincidências" de experiências de abortos espontâneos em uma mesma família, sugerem que as mortes in utero, especialmente os abortos de repetição, podem estar relacionadas à história da família. Para esses autores, pesquisando os antecedentes na família, confrontando datas e particularidades, pode-se encontrar o contexto específico desses abortos e descobrir o fio condutor que os une. A ideia é que a morte do bebê pode representar um eco de uma repetição familiar inevitável. Inevitável, porque a morte em outra geração não pôde ser compreendida, colocada em palavras e, então, engendra-se num processo de repetição. Nas palavras dos autores, "o nãodito faz um buraco (...) e são esses buracos que geram a repetição dramática, são as situações inelutáveis das quais não se sabe a origem e que fazem andar em círculos" (SZEJER; STEWART, 1997, p. 52). Nesse sentido, para os mais velhos 
da família, a morte de um bebê pode ter uma significação carregada de intenso sofrimento e despertar vivências e sentimentos que se encontravam recalcados.

Outra possibilidade é que os filhos estejam atravessando algo que eles nunca viveram, quando não houve outra morte fetal na família. Segundo Soubieux (2008), nesses casos, os avós podem se sentir desamparados face à situação e apresentar dificuldades para ajudá-los. Muitas vezes os avós são presentes, ajudam com os afazeres da casa, com os outros filhos, mas não falam abertamente sobre a morte ou sobre o bebê. A relação anterior entre os avós e os pais será importante para que os avós possam auxiliar nesse momento.

\subsubsection{O impacto do óbito fetal no profissional de saúde}

Conforme abordamos ao longo do capítulo, o óbito fetal afeta fortemente não só os pais, como os irmãos, os avós e o próprio casal. Contudo, esses não são os únicos personagens envolvidos nesse drama. A participação dos cuidadores implicados é crucial no impacto do trabalho de luto. Soubieux (2015) afirma que o reconhecimento e elaboração dessa implicação em um espaço reflexivo são essenciais.

Tanto em nossa sociedade como durante a formação de diferentes profissionais de saúde, a medicina é colocada como um instrumento de adiamento da morte. Cabe aos médicos e aos demais profissionais de saúde usar toda a tecnologia disponível para tentar impedi-la. Quando esse resultado não é atingido e a doença se agrava, a morte expõe o "fracasso" desses profissionais. Acreditamos que a questão de enfrentamento do óbito se torna ainda mais difícil quando relacionada ao início da vida, com vidas que deveriam estar começando. Para Klaus e Kennell (1992), um bebê que nasce morto configura uma inversão da ordem natural de eventos, o que torna o acontecimento tão difícil também para médicos e enfermeiros lidarem. Não costuma ser parte de suas funções, na sala de partos, facilitar a vinda da morte ao mundo. E é diante dessa sensação de fracasso e exposição que os profissionais estarão frente a um bebê sem vida. Essa pode ser uma explicação plausível para a dificuldade em lidar com essas situações, não conseguindo, muitas vezes, refletir sobre o que uma perda representa em suas vidas, nem ajudar os pais na difícil tarefa em que terão que enfrentar após o 
doloroso anúncio da morte. Esses profissionais terão que lidar com a dor dos pais, diante de suas próprias angústias e questões relacionadas a morte.

O caso de Mariana e Félix nos auxilia a ilustrar o sofrimento do profissional de saúde e também o impacto da forma como o profissional atua na vivência do luto da família. O casal vivia uma gestação com muita alegria e envolvimento quando, perto de seu final, em um exame de ultrassonografia, o médico não pôde escutar os batimentos cardíacos do bebê, sendo constatada a morte fetal. Foi indicada uma curetagem ${ }^{5}$ de emergência e os pais, muito abalados, foram ao hospital se encontrar com o obstetra que vinha lhes acompanhando. O médico, grande referência para os pais, manteve a cabeça baixa, dizendo apenas que "isso é mais frequente do que podemos imaginar".

Diante do choro desesperado de Mariana e dos soluços sufocados de Félix, a equipe de saúde começou a atendê-los, explicando que seria mais apropriado que o pai não participasse do procedimento cirúrgico, pois seria muito difícil para ele. Também foi explicado que Mariana seria sedada, pois estava muito nervosa e isso poderia ser muito prejudicial para ela, que precisava ser "forte". Mariana, em seu desespero, ainda tentou pedir a presença do marido, mas não tinha forças para argumentar e logo a anestesia começou a fazer efeito, de nada mais se lembrando. Quando acordou, estava tudo "limpo", nada que pudesse fazer referência à existência de seu bebê. Logo pôde ver seu marido e sua mãe que, ao seu lado, lhe confortaram e lhe disseram que "tudo estava resolvido e que tudo ficaria bem". Após a cirurgia, não foi atendida por seu médico habitual, mas por um de seus assistentes, que centrou o atendimento nas questões pós-cirúrgicas, sem referir-se à perda do bebê ou a suas causas.

Casos como este, infelizmente, são muito comuns nas maternidades e hospitais. Mostram não só um despreparo das equipes de saúde, que realmente não sabem como ajudar essas famílias, como uma tendência a escamotear o verdadeiro sentido da perda. Sedar a mãe e tirar o pai da cena diminui o sofrimento dos profissionais, uma vez que sem o desespero deles poderão trabalhar mais tranquilos, sentindo-se menos expostos em sua fragilidade. Dificilmente há uma reflexão sobre o que experienciaram, e, assim, pouco podem

\footnotetext{
${ }^{5}$ Procedimento médico executado em unidade hospitalar que objetiva retirar material placentário ou endometrial da cavidade uterina. Este método é necessário quando existem complicações após aborto médico ou aborto espontâneo.
} 
auxiliar efetivamente as famílias envolvidas em perdas. Parece-nos que esses profissionais realmente acreditam estar fazendo o melhor para as famílias, evitando um sofrimento maior. Entretanto, com suas condutas diante da morte, podem criar novos obstáculos à instalação do processo de luto dos pais. Nesse sentindo, Iaconelli (2007) ressalta que o tratamento dado aos pais, por parte dos profissionais de saúde, pode aumentar o potencial patológico deste tipo de perda. Binotto (2005) indica que os profissionais costumam recorrer a um mecanismo de negação do sofrimento associado a perda, para manterem-se íntegros na realização de seu trabalho. Essa postura é evidenciada na perpetuação de discursos e práticas que legitimam o direito dos profissionais de se manterem neutros e não se envolverem com a subjetividade do paciente, delimitando sua atenção aos aspectos físicos.

Mariana e Félix puderam dispor de pouquíssimos resquícios de seu bebê para iniciar seu processo de luto. Quando Mariana fala que tudo estava "limpo", referia-se à falta de algo que marcasse a existência de seu filho. Podemos pensar o quão difícil foi para esses pais iniciar seu trabalho de luto diante de uma perda não vista, não nomeada, não lembrada.

Por maior que seja o sofrimento nesse momento, podemos pensar que seria desejável que houvesse uma explicação para a morte, que os pais pudessem compreender as etapas de tudo o que ocorreu, que pudessem ter participado das decisões da escolha do tipo de parto que teriam, ainda que de um natimorto, que pudessem ter visto seu bebê e escolhido se queriam tê-lo segurado no colo ou the vestido. As clássicas banalizações, tanto da sociedade como dos cuidadores envolvidos, são, portanto, iatrogênicas, ao recusarem o sofrimento objetivo da realidade psíquica parental e não dar aos pais o direito de escolher o que desejam. Klaus e Kennell (1992) afirmam ser muito importante que os pais toquem o natimorto para tornar o evento real e facilitar o luto. Também enfatizam a importância de que mais pessoas próximas possam ver o bebê, se assim o desejarem.

Lewis (1976) enfatiza a importância de se estabelecer a identidade do natimorto e nos lembra que uma morte sem um corpo, que não tenha sido visto por seus pais, parece irreal. O luto após o nascimento de um bebê morto não conta com experiências a serem relembradas após o parto, sendo privadas de lembranças necessárias para a entrada no trabalho de luto. Esses pais são invadidos por um 
senso de não-existência, que supomos ser ainda maior em mulheres que estão sedadas durante o parto.

Segundo Soubieux (2014), para os cuidadores suportarem o desespero dos pais e, às vezes, também, suas raivas, mobilizam uma parte íntima deles próprios, de modo que o sofrimento psíquico dos profissionais do cuidado também deveria receber atenção. Além de ter que lidar com a morte do bebê, também têm que enfrentar várias tarefas difíceis, como encarar os pais portando terríveis notícias e receber seus sentimentos de tristeza e hostilidade. As instituições de saúde disponibilizam ainda pouco espaço para pensar situações de perdas com seus profissionais e famílias envolvidas em óbitos, tratando a perda numa maternidade como algo praticamente inaceitável nos dias atuais, especialmente quando diante de um acompanhamento pré-natal correto. Ainda segundo a autora, existe a necessidade de integrar o ensino do luto perinatal nas escolas e universidades.

Diante deste cenário, consideramos essencial a presença de um profissional sensível as diferentes escutas relacionadas à morte. A presença de um psicólogo ou psicanalista junto à equipe de saúde pode auxiliar na tentativa de compreensão dos afetos e emoções evocados em cada história. Esse profissional poderá atuar não só junto às famílias que perderam seus bebês, mas também expandir sua atenção e cuidado para os efeitos que essas perdas podem ter na equipe de profissionais.

Acreditamos que só assim os profissionais de saúde poderão verdadeiramente auxiliar as famílias enlutadas na expressão de seus sentimentos e pensamentos relacionados à perda, olhando, eles próprios, para suas dores e temores. Desse modo, acreditamos que estarão mais aptos a auxiliar os pais a elaborar sua perda e fazê-la real, atentando às necessidades individuais de cada família e ainda respeitando seu próprio direito de sentir determinada morte. 


\subsection{A interrupção de uma promessa}

Agora está tão longe ver,

A linha do horizonte me distrai Dos nossos planos é que tenho mais saudade Quando olhávamos juntos na mesma direção

Aonde está você agora Além de aqui,

Dentro de mim?

Renato Russo, Vento no Litoral

O nascimento de qualquer bebê já configura um momento de crise e traz consigo a necessidade de trabalhar alguns lutos. Acreditamos que diante da crise existencial que a gravidez convoca, a perda de um bebê neste cenário aumentará desmedidamente a intensidade dessa crise e, por conseguinte, exigirá remanejamentos ainda mais complexos. Soubieux e Caillaud (2015) indicam que a morte e a passagem por um terrível momento de crise e perturbação da identidade multiplicam ao infinito os efeitos conhecidos do pós-parto, configurando um verdadeiro traumatismo.

Lewis (1976) observou que, após o parto de um natimorto, a mãe experimenta um senso duplo de perda. $\mathrm{O}$ vazio é experimentado naturalmente pelas mães após o parto, mesmo com o nascimento de uma criança viva. Mas a sensação de perda é consolada pelo bebê real, que vai lhe ajudar a superar a estranheza de perder seu bebê de dentro. Com o natimorto, no entanto, a mãe deverá lidar com um vazio tanto interno quanto externo, uma vez que não há nada do útero e nada nos braços.

Importante lembrarmos que os afetos ambivalentes marcam a relação entre os pais e o bebê durante toda a gestação. Ao mesmo tempo em que o filho traz consigo expectativas de reparar falhas da história parental, provoca também a reativação de fantasmas edípicos e do desamparo inicial. Assim, é comum que o pai se sinta excluído da díade mãe-bebê e vivencie o bebê como um rival, reativando sua própria vivência infantil de se sentir excluído da relação dos pais, ou que a mãe se sinta inadequada na função materna por não con seguir abrir mão de um modelo idealizado (ZORNIG, 2010).

Ao pensarmos na ambivalência deste período, ressaltamos que, além dos conflitos edípicos, os pais podem revisitar também a sensação inicial de 
desamparo, que pode ser bastante desestabilizadora. Os bebês, por sua posição de vulnerabilidade psíquica e desamparo, provocam movimentos identificatórios arcaicos nos adultos que deles se ocupam, gerando medo de retornar a um momento de dependência. Para Freud (1926[1925]/1974) o desamparo liga-se à prematuração do ser humano, que nasce inacabado e totalmente dependente de outro que o proteja dos perigos do mundo exterior. O autor também ressalta que esse desamparo pode ser reavivado quando nos defrontamos com perdas e separações ao longo de nossas vidas. Acreditamos que o temor do retorno ao estado de desamparo anterior ao nascimento concretiza-se na morte fetal.

Esse acontecimento do luto pré-natal conduz todos os autores do drama a revisitarem seus próprios primeiros capítulos de suas vidas e reviverem esse período inquietante e angustiante onde o status de pessoa humana ainda é somente uma virtualidade. Embora fonte de todas as promessas, não se afasta jamais da sombra da precariedade ontológica desse período. Que a perda presente lembra com cinismo. (MISSONNIER,2015, p. 17, tradução nossa)

A ambivalência está presente durante todo o tempo da gravidez, porém o nascimento sem problema reinstaura o narcisismo materno ao the tranquilizar e lhe gratificar com um bebê saudável (MATHELIN, 1999). No entanto, diante de um bebê nascido morto, a mãe não encontra algo que lhe conforte, que lhe mostre que seus sentimentos hostis não prejudicaram seu bebê. Ao contrário, a realidade reencontra seus medos e fantasmas. Segundo a autora, "a realidade reencontra o fantasma e surge o trauma" (MATHELIN, 1999, p. 17). Para ilustrar essa questão trazemos a história de Bárbara e Matheus.

Em uma maternidade, fomos chamadas a realizar o atendimento de um casal que acabara de constatar a morte de seu filho durante uma consulta na emergência. Diante de muito sofrimento e choros descontrolados, Bárbara não parava de culpar-se pelo ocorrido. Culpava-se por não ter reduzido sua carga de trabalho, de ter usado salto-alto, de não ter marcado uma nutricionista. Matheus, seu marido, permanecia ao seu lado, tentando lhe dar suporte. É indicada a internação de Bárbara para se submeter ao parto e lhe é informado que ela precisa permanecer no hospital por 15 dias para um tratamento com antibióticos. Nesse período, Barbara continua a ser atendida pelo serviço de psicologia e pode começar a falar um pouco sobre seus fantasmas. 
Diz que adiou muito o desejo da maternidade, pois tinha medo de perder seu espaço na empresa onde trabalha. Relata que, mesmo tendo ficado mais de um ano tentando engravidar, quando descobriu a gravidez ficou muito assustada e chegou a pensar que seria melhor não ter engravidado. Achava que esse sentimento poderia ter prejudicado seu bebê. Outra fala que marcava sua ambivalência e fazia sentir-se culpada foi a descoberta do sexo do bebê. Bárbara e Matheus sempre quiseram um filho homem e, na ultrassonografia, decepcionaram-se ao descobrir que seria uma menina. Tinha medo de que a filha "tivesse se sentido rejeitada". Matheus era muito presente e sempre procurava confortar sua esposa, dizia saber que o sofrimento da esposa era maior do que o seu, porque "foi no corpo dela". Bárbara dizia que sentia que tinham arrancado uma parte dela. Sentiam-se completamente impotentes e fragilizados.

A gravidez de Bárbara e Matheus confirma a presença da ambivalência natural deste período. $\mathrm{O}$ desejo apontava para duas direções contraditórias, mas coexistentes: ter o filho e adiar esse momento. O nascimento do filho tranquilizaria seus pais, apresentando-lhes um bebê saudável que faria com que pensamentos negativos sobre o não desejo pela gravidez permanecessem em segundo plano, visto que a vinculação com o bebê real seria preponderante. No entanto, sem um bebê, são justamente os pensamentos hostis que experimentaram ao longo da gestação que se colocam no centro da cena, fazendo com que se sintam culpados por sua morte.

$\mathrm{O}$ encontro com o filho real requer o abandono das representações idealizadas. Segundo Stern (1997), após o nascimento a mãe começaria a reconstruir essas expectativas baseadas no que lhe é oferecido pelo bebê real. Nos casos de óbito fetal, o contato com o bebê real só pôde ser vislumbrado nas ultrassonografias, não tendo ocorrido efetivamente esse contato, o que aumenta a dificuldade da elaboração do luto do filho imaginário. Os pais ficam, de certa forma, aprisionados a tudo que projetaram para seus filhos em uma visão ideal, mais difícil de ser abandonada.

Uma situação contraditória é evocada entre o intenso investimento psíquico do feto durante a gravidez e o imediato desinvestimento que é imposto após o anúncio da morte. Certa vez, fomos confrontados por uma mulher que se queixava de que sua obstetra nas consultas pré-natais sempre chamava seu bebê 
pelo nome que haviam escolhido e, no dia em que souberam da morte, lhe disse apenas que o "feto não apresentava mais batimentos cardíacos".

O óbito fetal ocorre justamente no momento em que estão sendo traçadas as primeiras formas de relacionamento entre a mãe e o bebê, de tal modo que, nesse período, as dimensões de indiferenciação e de diferenciação oscilam. Devido a isso, acreditamos que o óbito nesse período é potencialmente problemático e tende a ser vivido como traumático, uma vez que o objeto de amor perdido não está firmemente reconhecido como objeto real. O que é perdido é um objeto virtual, uma relação de objeto virtual, vivida com muita ambivalência.

Como trabalhamos anteriormente, o feto enquanto objeto virtual funciona como operador simbólico entre a realidade e a fantasia, fazendo reviver a angústia e os conflitos da infância. Quando o bebê morre nesse momento, a mãe é lançada num grande conflito, pois terá que se haver com suas identificações com a criança que foi (que foram convocadas), diante da interrupção da constituição de uma identidade parental. Angústias edipianas e de abandono estarão presentes sem que haja a compensação vinda da vinculação com o filho e da afirmação da capacidade de procriação. A mulher e o homem destituídos de suas capacidades de manter a criança viva não poderão investir no feto, comunicar-se com ele.

Refletimos, então, que a singularidade deste trabalho de luto comporta um duplo componente: narcísico e objetal. Fazer o luto do bebê perdido é também fazer o luto de partes infantis de si mesmo, de conflitos não resolvidos, das relações idealizadas, fazer o luto de ser pai e de ser mãe diante da sociedade, fazer o luto de tudo o que foi projetado naquele bebê que não nasceu. O lugar do feto morto, no psiquismo dos pais, não será o mesmo em todos os casos. Os embriões e os fetos são para cada pai, cada casal, um objeto de investimento singular entre as polaridades de investimento narcísico (um prolongamento de si) e investimento objetal (uma criança estrangeira). Cada família e cada história apresentarão as suas particularidades e suas "bagagens" que irão predispor a rumos diferentes.

Se retomarmos o conceito de preocupação materna primária de Winnicott, podemos pensar que, quando um bebê morre prematuramente, a mulher se vê obrigada a desligar-se desse estado abruptamente. Nas palavras de Winnicott, "se o bebê morre, o estado materno surge repentinamente como uma doença. A mãe assume esse risco" (1956/1978, p. 494). 
Algumas mães, mesmo diante do conhecimento de uma má formação ou diante de uma ameaça de parto extremamente prematuro, poderão desenvolver a sensibilidade exacerbada para conseguir se identificar com seu filho, já no final da gestação. Nesse caso, estarão descentradas de si e identificadas com a fragilidade e dependência do filho. Suas próprias defesas estarão comprometidas e viver a morte do filho será algo extremamente penoso, podendo colocar sua saúde em risco. A mulher vivia um estado especial de preparação para a maternidade, iniciando um processo de investimento narcísico em seu bebê, contudo subitamente o trabalho psíquico a realizar se modifica bruscamente.

A mulher que estiver no estado de transparência psíquica (BYDLOWSKI, 2002), com sua atenção psíquica voltada para dentro, sob os ecos de seu narcisismo, irá se deparar abruptamente com o fracasso da possibilidade de reparação narcísica que seu bebê representava. Morre um bebê que, de certa forma, representava, em alguns momentos, ela mesma. Nessa perspectiva, a morte é sentida como uma amputação, uma perda de um pedaço de si própria, tal como é evidenciado por Bárbara ao sentir que arrancaram um pedaço dela.

Também através desta perspectiva, Klaus e Kennell (1992) afirmam que a morte fetal envolve a perda de uma parte do self, na medida em que o bebê/feto permanece como parte do self dos pais, e assim, portanto, equivaleria à amputação ou à perda de uma função do corpo - como a fala de Bárbara revela. Dessa forma, exigiria uma readaptação na própria imagem e da forma de viver, podendo leválos a pensar em si próprios como seres humanos imperfeitos. Por outro lado, não podemos deixar de destacar (conforme discorrido no capítulo anterior desta dissertação) que o bebê não intima somente representações familiares, com sua morte também falece a parte enigmática presente neste bebê. A morte do "estrangeiro", que permanecerá ainda mais enigmática, lançando a mulher em uma revivescência do seu desamparo inicial. Através dessas reflexões, os autores propõem que as respostas dos pais a um natimorto representam um processo muito mais difícil do que outros lutos, mesmo se comparado a perdas de familiares próximos. Supomos que a morte de um filho na gestação pode adquirir um forte efeito destrutivo para os pais, pois exige um trabalho psíquico muito intenso, na contramão do que estavam se preparando. 


\subsection{Trabalho subsequente à perda do objeto de amor}

E assim, chegar e partir

São só dois lados

Da mesma viagem

O trem que chega

É o mesmo trem da partida

A hora do encontro

É também despedida

Milton Nascimento, Encontros e despedidas

No texto Luto e melancolia, Freud (1917[1915]/1974) descreve o processo de luto como o trabalho subsequente à perda de um objeto de amor, como uma das reações possíveis diante da perda de um objeto querido. Conforme Garcia-Roza (2004) explicita, trata-se de um forte vínculo amoroso que é perdido no objeto e que tem que ser desfeito para dar lugar a outros vínculos. Isto é, para que torne possível a relação amorosa a outros objetos. No luto, a perda do objeto provoca um desinteresse pelo mundo externo, com exceção daquilo que está relacionado ao objeto de amor perdido. Apenas aqueles que evocam o objeto perdido despertam interesse, de forma que não será possível a escolha de um novo objeto de amor enquanto seu processo não tiver terminado. Tal reação, mesmo parecendo prejudicial ao sujeito, não pode ser considerada uma patologia e é, segundo Freud, um evento normal da vida, gerador de um estado de ânimo doloroso que demanda tempo e uma grande quantidade de energia para sua superação. Freud nos indica que se trata de um processo, um trabalho psíquico, cuja função é a elaboração e assimilação psíquica da perda, bem como possibilitar a separação do objeto perdido e o reinvestimento em um novo objeto.

No artigo citado, Freud (1917[1915]/1974) afirma que um trabalho de luto bem sucedido começa com o teste de realidade, isto é, a constatação de que houve a perda. Só através desta constatação é que se pode ter consciência de que o objeto amado já não existe e, consequentemente, toda libido deverá ser retirada de suas ligações com ele. No entanto, conforme observa Garcia-Roza (2004), a partir da leitura de Freud, "ninguém abandona de bom grado um objeto de amor, pelo menos de maneira imediata" (p. 74). A exigência de retirar a libido das ligações com o objeto perdido provocará uma grande oposição, que só poderá ser superada pouco a pouco. Freud pontua que cada uma das lembranças e expectativas 
isoladas, através das quais a libido está vinculada ao objeto, deverá ser evocada e hipercatexizada, e o desligamento da libido se realizará em relação a cada uma delas. Nesse sentido, Garcia-Roza (2004) conclui que a inibição do eu e a restrição de seu campo de atividades podem ser explicadas pelo fato do eu estar ocupado com o trabalho de luto. Freud afirma que, quando o trabalho de luto se conclui, o ego fica novamente livre para novos investimentos.

Pinheiro, Quintella e Verztman (2010) fazem uma leitura do luto como um movimento de elaboração psíquica da perda que permite reinserir o sujeito no circuito desejante, através de um trabalho de ligação e integração daquilo que invade o sujeito. O luto tem por função "matar o morto, dando a ele um lugar simbólico subjacente à elaboração, também simbólica, da perda” (p.7). Assim, percebemos como esse trabalho funciona como propulsor de uma elaboração da perda e permite uma assimilação simbólica da experiência vivida. Quando o luto é possível, o sujeito poderá preservar algo do objeto perdido através de uma identificação feita por traços, na qual o sujeito recolhe um traço para identificação, pressupondo que algo lhe escapa.

Freud (1917[1915]/1974) indica que a melancolia também pode se constituir como reação à perda de um objeto amado. $\mathrm{O}$ autor faz uma analogia entre os conceitos de luto e de melancolia por serem processos semelhantes. Em ambos, há perda de objeto e diminuição de interesse pelo mundo, com a consequente incapacidade de estabelecer novas relações amorosas. Entretanto, na melancolia, não se está claro o que foi perdido, como no luto. Freud afirma que "mesmo que o paciente esteja cônscio da perda que deu origem a sua melancolia, mas apenas no sentido de que sabe quem ele perdeu, mas não o que perdeu nesse alguém" (p. 277). Mostra-nos, assim, que a melancolia está relacionada a uma perda objetal desconhecida, que não é localizável como no luto, pois está retirada da consciência. Ao mesmo tempo que a perda é evidente, ela é inteiramente desconhecida para o melancólico.

Outra diferença apontada por Freud entre a perda objetal que caracteriza o luto e a que caracteriza a melancolia é que, no luto, é o mundo exterior que perde o interesse, enquanto na melancolia é o próprio eu. O melancólico apresenta grande empobrecimento do eu, se desvaloriza e se degrada, afetando diretamente sua autoestima. Freud chama atenção para a forma despudorada em que o melancólico expõe seus defeitos, levantando a suspeita de que não é dele mesmo 
que se trata, pois não há sentimentos de vergonha ou tentativa de esconder suas falhas. Esses pensamentos hostis e atos de flagelo dirigidos à própria pessoa permite a Freud pensar que uma parte do eu coloca-se contra outra parte do eu, tomando-a como objeto. As autotorturas que a pessoa se inflige parecem se ajustar ao objeto amado que não pôde ser renunciado, embora o próprio objeto de amor não esteja mais presente. A saída poderá ser se refugiar na identificação narcisista e o ódio, então, entra em ação nesse objeto substitutivo (o próprio eu). Ocorre o que Freud denomina de autotortura da melancolia, segundo a qual trava-se inúmeras lutas em torno do objeto, nas quais o ódio e o amor se enfrentam no inconsciente e o ódio pelo objeto perdido será dirigido ao próprio ego. Assim sendo, na melancolia, ao invés da libido investida no objeto perdido ter sido deslocada para outro objeto, foi recolhida para o eu e serve para estabelecer uma identificação no eu com o objeto abandonado. Portanto, o que no luto era uma perda de objeto, na melancolia transforma-se em uma perda do eu (GARCIAROZA, 2004).

No óbito fetal, faltam dados que comprovem a realidade da perda, mas também da própria existência do bebê. Ele não chegou a nascer e, portanto, o teste de realidade fica bastante comprometido. Não há a revelação, por parte da realidade, de que o objeto de amor não existe mais. Conforme nossas reflexões iniciais, o objeto perdido não foi um objeto real, mas um objeto em potencial, virtual ainda. Somado a isso, há o fato de o bebê não ter tido sua existência compartilhada com outros familiares, que acabam desacreditando da dor que os pais sentem, assim como vimos nos casos de Ana e de Mariana e Félix. A partir dessas considerações, podemos inferir o quão difícil será para esses pais iniciarem o processo do luto, pois a morte do bebê os lança em um estado de confusão, sendo muito penoso abandonar sua posição libidinal de ligação ao objeto perdido.

A referência a uma perda desconhecida na melancolia nos faz lembrar o estatuto virtual do objeto perdido nos casos de óbitos fetais. Através de observações clínicas, notamos como o conhecimento do que foi perdido com a morte do feto é confuso. A mulher e o homem não sabem exatamente o que perderam quando seu bebê morre antes de nascer. Nessa criança esperada havia muitas representações, projeções e expectativas. Quando são tomados pelo vazio da morte, os pais perdem tudo o que o bebê significava e, com frequência, são 
tomados por um sentimento de inferioridade, de fracasso, indignidade e mesmo vergonha.

A melancolia se apresenta como um caminho (possível, ainda que precário) às mães que perderam seus bebês e não conseguiram iniciar um processo de luto. Podem lançar mão, assim, de outro trabalho interno, que apresenta certa similaridade ao luto, mas que não libera seu ego para fazer novos reinvestimentos. Nesse caso, a libido livre não será deslocada para outro objeto, mas retirada para o ego, estabelecendo-se uma identificação do ego com o objeto perdido. Neste contexto, se a identificação, conforme a proposição freudiana é a primeira forma pela qual o ego escolhe um objeto, a identificação melancólica representa uma regressão de tipo de escolha objetal. Assim, numa tentativa de não reconhecer a perda, observamos a frequente incorporação ${ }^{6}$ do objeto perdido no ego da mãe, como uma sombra, tal como descrito por Freud (1917[1915]/1974) a respeito da identificação melancólica.

A identificação na melancolia se apresenta, antes de tudo, como um modo de garantir a permanência do vínculo amoroso apesar da perda do objeto. Pinheiro (1993) verifica que, na melancolia, a perda é recusada, e através da identificação narcísica, o melancólico mantém o objeto dentro de si: "Nesse caso, portanto, é como se a identificação trouxesse o objeto in toto, em bloco. Na ausência da dialética identificatória feita por traços, o objeto torna-se por assim dizer um posseiro que ocupa o espaço egóico" (p. 53). A pessoa não consegue se apropriar subjetivamente do objeto através da identificação por traços, só pode fazê-lo objetivamente. Quando o trabalho de luto é possível, o objeto será aos poucos abandonado e substituído por outro. Isso prova que o objeto é reconhecido como incompleto e portador de falhas, contrariamente ao objeto na melancolia que se apresenta como absoluto e completo, por isso o investimento em outro objeto e a elaboração simbólica das perdas serem possíveis no luto e não na melancolia. (PINHEIRO, 1993).

Freud (1917[1915]/1974) observa que as pré-condições para que a melancolia se instaure são forte fixação no objeto e uma escolha objetal de forte base narcísica. A identificação narcisista com o objeto, facilmente pensada no caso das mães com seus bebês, se torna um substituto do investimento libidinal.

\footnotetext{
${ }^{6}$ No tópico seguinte nos deteremos à explicação do fenômeno da incorporação.
} 
$\mathrm{Na}$ identificação, o ego incorpora em si esse objeto. Essa opção parece estar mais disponível a essas mães, se lembrarmos de que no processo de construção da maternidade, elas encontram-se num estado de regressão psíquica.

Freud (1917[1915]/1974) também cita os conflitos devido à ambivalência como pré-condições da melancolia. Na perda fetal, a relação dos pais com o objeto perdido é bastante complexa, nos fazendo pensar no potencial melancólico que ela implica. Anteriormente neste trabalho, com auxílio do caso de Bárbara e Matheus, indicamos como essa relação, além de ser pautada em uma virtualidade, é atravessada por uma série de representações carregadas de ambivalência.

Como já observado, na metapsicologia da melancolia, uma parte do ego se opõe a outra (FREUD, (1917[1915]/1974). Pinheiro (1993) observa que o objeto incorporado ao ego pela identificação melancólica, passa a exercer uma função superegóica ${ }^{7}$, trazendo um tom ditatorial que revela a presença de forte conflito entre as instâncias do ego e do superego. A autora indica que a melancolia instaura uma clivagem, na qual ocorre uma divisão, em que as partes se ignoram, não se comunicam, não são capazes de afetar uma a outra. É preciso ressaltarmos que a noção de superego, tal como exposta por Freud em 1924 em "O eu e o isso", ainda não existia quando o autor escreveu "Luto e melancolia"(1915), no entanto, o autor se utiliza das noções de Ideal do eu e eu Ideal para falar da existência de um agente crítico excessivamente presente e cruel indicada pelas acusações que o sujeito melancólico dirige a si próprio.

Evocamos essas apreciações sobre a melancolia, por observamos que muitas mães que perdem seus bebês durante a gravidez têm muita dificuldade em iniciar um trabalho de luto. Impossibilitadas de abrir mão do objeto de amor, lhe restará buscar reencontrar esse objeto incessantemente. Isso pode sobrecarregar a história da família e dos filhos que possam vir após essa perda não enlutada.

Soubieux (2014) ressalta que o lugar do feto morto no psiquismo dos pais não será o mesmo para todos. O tempo do luto será o tempo de conceber que essa vida existiu e deixou de existir. No entanto, por seu caráter narcisista, o luto pode levar à constituição do feto como objeto de melancolia, mas é importante observarmos que esse não é o único destino. A elaboração do luto fetal é possível, mas sempre será carregada de muito sofrimento. Uma contribuição importante

\footnotetext{
${ }^{7}$ Apesar de reconhecer a importância da dimensão superegóica na melancolia, este não será o foco deste trabalho, restringindo-nos a sua alusão.
} 
desta autora nos indica que um primeiro momento pode ser caracterizado por um tempo de identificação melancólica e depois vir a evoluir para um trabalho de luto. Partindo do pressuposto que o feto representa ainda um objeto virtual, muito próximo às imagens dos ideais dos pais (uma vez que a criança como objeto virtual ancora-se no imaginário parental, acrescidos de algo do próprio bebê), percebemos como facilmente pode mostrar-se como um objeto absoluto, completo, sem falhas, portanto, dificultando uma identificação por traços. O bebê morre antes de ser possível uma identificação com o objeto, uma apropriação subjetiva, assim os pais podem ter que valer-se da identificação melancólica como parte do processo de luto, para que seja possível uma identificação com o objeto, ainda que com o objeto absoluto, para que aos poucos possa se fazer um trabalho de reconhecimento da incompletude do objeto de amor, o que poderá possibilitar a gradual separação deste. Dessa forma, quando a elaboração dessa perda se tornar possível, pode permitir uma reconstrução psíquica surpreendente.

E mesmo quando o trabalho de luto é possível e segue seu caminho, Soubieux (2008) enfatiza que, normalmente, se trata de um processo muito longo e paradigmático, pois se reaviva e prossegue durante os acontecimentos da vida e datas de aniversário, especialmente durante as próximas gestações (tanto do casal como de pessoas próximas). Mas a autora pontua que a reativação do luto pode não ser problemática e pode gerar um processo criativo permitindo prosseguir na elaboração.

Missonnier (2015) ressalta que o feto é um objeto narcísico e objeto parcial em vias de objetalização. Neste sentido, o óbito fetal confronta os pais com a necessidade de fazer um trabalho de luto de um objeto que ainda é uma promessa virtual. Ou seja, os pais não são confrontados com a perda de um objeto externo, mas sim com a interrupção de uma promessa. Nesse caso, a mãe precisará se identificar não com o objeto morto, mas com o objeto interno virtual e, gradualmente, deixar morrer uma parte de si mesma, tal qual uma amputação. Por esta particularidade, a ameaça melancólica é consideravelmente maior nos casos de luto pré-natal do que em outros tipos de lutos clássicos, como nos apresentou Freud em Luto e melancolia (1917[1915]/1974). 


\subsubsection{Introjeção x incorporação}

Para pensar sobre os processos que podem se seguir à perda de um objeto de amor e refletir sobre a questão da identificação na melancolia, nos parece importante fazer uma breve consideração acerca de dois conceitos fundamentais: a introjeção e a incorporação. Analisaremos esses conceitos baseados nas teorias de Abraham e Torok que, por sua vez, têm como referência fundamental o pensamento de Ferenczi.

Abraham e Torok (1968/1995), inspirados em Ferenczi, descrevem a introjeção como um mecanismo psíquico que promove a expansão do eu através da eliminação de recalcamentos, provocando algo como uma inclusão do inconsciente no eu. Esse é o processo através do qual o eu se utiliza para tomar para si o conjunto de pulsões que estão investidas em um objeto. Nesse movimento, a introjeção possibilita que as experiências pulsionais passem pela linguagem e possam ser articuladas em palavras. Para tal, o papel do outro na introjeção é essencial, uma vez que somente o outro enquanto objeto pode garantir ao sujeito que suas experiências pulsionais possam ser referenciadas à linguagem. Para os autores, a introjeção é o processo responsável pela entrada do sujeito no jogo objetal.

Pinheiro (1995) amplia o conceito de introjeção, descrevendo-o como o processo que visa introduzir na esfera psíquica não o objeto, mas as representações que povoam o mundo simbólico do mesmo. Desta forma, a introjeção é entendida como um processo de apropriação de sentido, possibilitando que o sujeito processe uma experiência emocional. Portanto, não podemos considerá-la apenas como um mecanismo de defesa, mas como um processo pertencente ao aparelho psíquico que leva a estruturação e expansão do mundo simbólico.

Se afirmarmos que a introjeção é um processo estruturante do aparelho psíquico, podemos compreender que eventos externos potencialmente traumáticos que forem elaborados e vivenciados com mediação do objeto poderão ser introjetados e transformados. Sendo assim, mesmo que um evento seja considerado traumático e doloroso, como uma perda fetal, se ele for introjetado, o aparelho psíquico poderá se reestruturar. 
Quando a introjeção falha, quando ela é incapaz de seguir seu caminho, outro mecanismo é convocado: a incorporação. Para a incorporação entrar em ação é preciso que o trabalho de introjeção tenha começado, mas tenha sido impedido por um obstáculo proibitivo que incide na linguagem, impossibilitando a articulação das palavras, de acordo com Abraham e Torok (1968/1995). Os autores afirmam que "não vindo palavras da boca preencher o vazio do sujeito" (p. 247), este introduz no lugar uma coisa imaginária. Como um "artifício desesperado", diante da introjeção impraticável, a fantasia de incorporação aparece como substituta da introjeção.

A incorporação é um mecanismo fantasmático que surge como uma compensação do prazer perdido e da introjeção ausente, realizando a instalação do objeto proibido no interior de si. Tem por objetivo recuperar, de forma mágica e oculta (e não através de um processo, como ocorre na introjeção), um objeto que por alguma razão não pode ter o seu desejo introjetado (ABRAHAM \& TOROK, 1968/1995).

Abraham e Torok (1968/1995) salientam que a incorporação só pode ser pensada quando se tratar da perda súbita de um objeto narcisicamente indispensável que não consegue ser falado; que não pode, por alguma razão, ser confessado enquanto perda. Impossibilitado de articular palavras sobre o que aconteceu, restará ao sujeito a introdução de uma coisa imaginária em si. No entanto, as palavras indizíveis e ligadas a lembranças de alto valor libidinal e narcísico não se acomodam a sua exclusão. E não vão cessar de "reclamar seus direitos".

O luto indizível instaura no sujeito uma "sepultura secreta", um complexo fantasístico inconsciente que leva uma vida separada e oculta, como uma espécie de antiintrojeção, que Abraham e Torok (1968/1995) denominam de inclusão. Trata-se de uma identificação oculta e imaginária, que consiste em trocar sua própria identidade por uma identificação fantasística com um objeto já perdido por efeito de um traumatismo, na tentativa de manter uma ilusão anterior a do traumatismo.

Enquanto o mecanismo da introjeção remete às pulsões, a incorporação refere-se aos objetos em si. A introjeção das pulsões põe fim à dependência objetal, enquanto a incorporação do objeto cria ou reforça essa dependência. O 
objeto incorporado, exatamente no lugar do objeto perdido, lembrará sempre alguma outra coisa perdida. Nas palavras da autora:

Em caso de luto, a natureza deste será função do papel que desempenhava o objeto no momento da perda. Se os desejos que lhe concernem foram introjetados, nenhum desabamento, doença do luto ou melancolia devem ser temidos. A libido que tinha investido o objeto acaba por ser recuperada pelo Ego e - de acordo com a descrição freudiana - estará novamente disponível para se fixar em outros objetos necessários à economia libidinal. E, é verdade que o trabalho de luto não deixa de ser - mesmo nesses casos - um processo doloroso, mas a integridade do ego garantirá a saída. O mesmo não ocorre quando o processo de introjeção permanece inacabado. Tendo a parte não assimilada das pulsões se fixado em Imago - sempre reprojetada em algum objeto externo. (TOROK, 1995, p. 225)

A Imago a que Torok se refere é constituída para encarnar o objeto externo, numa tentativa de manter a esperança de ter o seu desejo realizado. $\mathrm{O}$ objeto investido de tal papel imaginativo não poderá morrer, de modo que será impossível iniciar um trabalho de luto, já que não se poderá renunciar ao objeto.

O trabalho de luto configura uma reestruturação psíquica e, portanto, pressupõe o mecanismo da introjeção. Através de um processo longo e doloroso, as representações do objeto perdido podem ser introduzidas no mundo interno do sujeito, libertando a carga libidinal que estava presa ao objeto. Pensando acerca da morte fetal, quando esta pode ser devidamente introjetada, passando pela articulação das palavras e da linguagem, ela poderá fazer seguir o curso do luto e prosseguir.

No entanto, conforme apontamos no tópico anterior, ao inferirmos a frequente saída pela melancolia, essa introjeção nos parece muito complicada pelo estatuto confuso do objeto perdido. Vimos o quanto a ligação dessa experiência emocional da perda com a linguagem é difícil para todos os envolvidos. Sem palavras que venham dar sentido a essa perda traumática, resta ao sujeito "engolir" tal experiência.

Todas as palavras que não puderam ser ditas, todas as cenas que não puderam ser rememoradas, todas as lágrimas que não puderam ser vertidas, serão engolidas, assim como, ao mesmo tempo, o traumatismo, causa da perda. Engolidos e postos em conserva. (ABRAHAM; TOROK, 1995, p. 249)

O sujeito será lançado numa tentativa de suprimir a ideia de uma lacuna, e assim poderá se fixar numa imago e manter a dependência ao objeto. A mãe não 
pode ter o seu bebê e o que ele representava, mas pode não conseguir abrir mão disso. Para manter esse objeto ideal a qualquer custo, ela poderá incorporá-lo dentro de si, mesmo que isso prolongue indefinidamente o seu sofrimento. Absorver o objeto que falta imaginativamente no momento em que o psiquismo está enlutado é recusar o luto e suas consequências, é recusar saber o verdadeiro sentido da perda, é recusar sua introjeção.

Segundo Torok (1968/1995), a incorporação está na base da experiência melancólica e se apresenta como algo ligado a experiência traumática que encontra-se impossibilitada de se inserir psiquicamente. Ao invés de introjetar o objeto perdido, através da atribuição de sentido, ocorre uma incorporação maciça desse objeto por fantasia. Na melancolia, o sentimento de existência de si mesmo torna-se extremamente frágil perante a onipotência do outro incorporado na identificação narcísica (PINHEIRO, QUINTELLA \&VERZTMAN, 2010). A não inscrição psíquica da perda do objeto perante a fragilidade narcísica do melancólico, acarreta a permanência do objeto clivado dentro do próprio eu. Para ilustrar essa dificuldade de introjeção diante da perda fetal, traremos dois fragmentos clínicos.

O primeiro é o caso de Rebeca e Márcio, que engravidam de Marcela. O casal vivia uma gestação com muita alegria, compartilhada por todos seus familiares. Com 22 semanas de gestação, Rebeca não consegue mais detectar os movimentos fetais e, ao irem a uma emergência, constatam que Marcela havia morrido. Rebeca não se desfaz do quarto, nem das roupas de Marcela e diz, com muito sofrimento, que deixará tudo como está para quando a nova filha vier. Passado algum tempo, Rebeca engravida de novo e, com nove semanas de gestação, sofre uma nova perda. Começa a investigar possíveis causas para as perdas fetais e descobre que possui uma patologia uterina que dificulta que a gravidez siga seu curso. Volta-se para tratamentos com ajuda de tecnologias para que consiga engravidar. Submete-se a um desgastante processo de fertilização in vitro e engravida novamente. Com dez semanas de idade gestacional, passa por mais uma perda. Márcio fica ao lado de Rebeca, mas mostra um grande desgaste com todas as tentativas e frustrações. Márcio tenta convencer Rebeca a adotar uma criança, mas Rebeca é veementemente contra, diz que precisa ter "um bebê seu”. Quando Rebeca decide iniciar um novo tratamento para engravidar, Márcio 
pede o divórcio. Mesmo divorciada, Rebeca continua planejando nova inseminação artificial, agora com doação de espermatozoide.

O outro caso que acreditamos que irá nos auxiliar na compreensão e ilustração das questões que estamos propondo traz a história de Flávia e Jorge, que engravidaram de Leonardo. Gestação tranquila, fizeram o enxoval e decoraram o quartinho de Leonardo com muita alegria. Durante um exame de rotina, descobriram que ele era portador de uma síndrome incompatível com a vida e, com 33 semanas de gestação, é detectada sua morte. Apesar da morte de Leonardo, Flávia precisa se submeter a um parto normal, onde nasce um filho morto. Todos ficam muito abalados, porém pouco falam sobre Leonardo, depois do parto. Flávia, após curto tempo de licença médica, volta ao trabalho e passa a se dedicar intensamente a seu ofício, acreditando que assim "seria mais fácil esquecer". O quartinho e os pertences de Leonardo simplesmente desapareceram. Flávia não sabia quem teria sido o autor daquele desaparecimento, embora desconfiasse de sua irmã. No início, a família manifestou seu pesar de forma ambígua, reforçando que foi "melhor morrer do que nascer com problema". Com o tempo, pararam de falar sobre o ocorrido.

Passados oito meses da morte de Leonardo, Flávia engravida de novo. Uma gravidez que apesar de "planejada" foi vivida cheia de medos e sustos. Flávia e Jorge não conseguiam comprar nada para o bebê, também não conseguiram montar um quarto para ele. Flávia teve sangramentos logo no início da gestação e foi orientada a permanecer de repouso em casa. Flávia em casa, "parada", não parava de pensar em Leonardo. Por mais que tentasse não pensar nele, não conseguia. Apesar dos médicos afirmarem que a síndrome de Leonardo não tinha componente hereditário, ela tinha certeza que viveria exatamente a mesma experiência. Certeza que, para ela, foi reforçada quando descobriu que seria outro menino. Resolveram que iriam chamá-lo de Rafael. Passaram a tentar se referir a ele pelo nome escolhido, mas tanto o pai como a mãe só conseguiam chamá-lo de Leonardo, em alguns casos misturavam os nomes, chamando-lhe de "Rafaleo". A evocação do filho morto causava tanto desconforto nos pais que estes resolveram que seria melhor chamar o novo filho também de Leonardo, “assim não teria confusão".

Tanto no caso de Rebeca como no caso que chamamos de "Rafaleo" observamos que o trabalho de luto não pôde se iniciar de forma satisfatória. 
Rebeca não parece ter conseguido introjetar as representações que povoavam o mundo simbólico, ligadas ao objeto bebê, permanecendo ligada ao objeto em si. Em uma tentativa desesperada de não perder para sempre esse bebê, mostra-se aprisionada nessa busca, redirecionando todos seus investimentos libidinais para esse objetivo e, com isso, sacrificando inclusive seu casamento. Parece ter recusado o sentido verdadeiro da perda, procurando acreditar que poderia recuperar o seu filho. Não foi possível uma articulação entre a experiência vivida e a sua elaboração simbólica. A experiência não pôde ser referenciada à linguagem, não pôde ser introduzida em uma cadeia psíquica. Assim, Rebeca permaneceu completamente dependente ao objeto, tornando difícil o redirecionamento da energia libidinal.

Flávia e Jorge entraram em uma nova gestação ainda sem realizar o trabalho de luto por Leonardo. Não tendo conseguido introjetar completamente a representação do filho em seu psiquismo, tornou-se difícil dar um lugar diferente ao novo filho, estando mais disponível a possibilidade de colar as duas representações, como se pudessem recuperar o objeto perdido dessa forma.

Vimos neste capítulo que o luto fetal, por seu caráter narcisista, pode levar à constituição do feto como objeto de melancolia e pode, inclusive, passar por um primeiro tempo melancólico e evoluir para um trabalho de luto. Quando for possível para o sujeito o escoamento da carga libidinal ligada a investimentos e lembranças relacionadas ao objeto perdido, gradativamente o objeto poderá ser desinvestido, permitindo, assim, ao eu eleger e investir em outro objeto na realidade. Ao entrar no processo do luto, não excluirá a lembrança do objeto perdido no psiquismo, mas essa lembrança não ocupará mais o mesmo lugar que antes ocupava.

Ao longo deste capítulo procuramos apontar e justificar o porquê da melancolia constituir uma opção, por vezes, mais disponível aos pais diante da morte do filho. Porém, cada história sempre implica em algo singular, o que não nos permite apontar tendências. $\mathrm{O}$ óbito fetal para algumas mulheres pode incitar diferentes evoluções. Soubieux (2008) aponta que a morte fetal pode desencadear, além da melancolia, um quadro de mania, uma patologia nostálgica, uma somatização ou ainda uma crise psicótica. Não entraremos nessas outras direções, mas acreditamos ser importante marcar que existem muitas possibilidades que, de 
acordo com as possibilidades internas e a qualidade do ambiente de cada sujeito poderão ser acionadas diante de tal perda.

Faz-se importante ressaltar ainda que, diante da morte fetal, alguns pais conseguirão reagir à perda de forma surpreendente, sendo capazes, à custa de um longo e doloroso processo, de elaborar a perda e inseri-la simbolicamente. Outros pais, após um tempo melancólico, poderão reativar o luto e gerar um processo criativo, permitindo prosseguir na elaboração. Na última parte deste trabalho, nos dedicaremos a refletir sobre as construções psíquicas possíveis diante de uma perda fetal. 


\section{Construções face à perda}

Você não pode evitar que os pássaros da tristeza voem sobre sua cabeça, mas pode evitar que eles construam ninhos em seus cabelos.

Provérbio Chinês

Quando o silêncio invade o cenário onde a morte se instala, a elaboração será muito mais penosa. Mathelin (1999) enfatiza que o trauma surge na falta de palavras que venham dar sentido ao ocorrido, pois o trauma é "sem fala, ele permanece sem palavras porque é por definição impensável” (p. 17). Sem que se falem dos fetos mortos e da morte em si, a entrada dessa experiência na vida simbólica dos envolvidos será um grande desafio, e a sombra dessa vida interrompida poderá perpassar gerações. Ao longo deste terceiro capítulo, procuraremos refletir sobre as construções psíquicas possíveis diante de uma perda fetal.

\subsection{Criatividade e espaço potencial}

Os pais que perderam tão precocemente seus filhos terão que descobrir uma forma de fazer face ao insuportável desta perda. Alguns casais engravidam de novo muito rapidamente, outros se afastam do convívio com crianças. Soubieux (2014) indica que cada um vai ter que inventar algo a partir de si mesmo para suportar a vida e que, às vezes, isso se dá por meio de sublimação - como na arte e na escrita. A autora sensivelmente percebe que são não somente tentativas de elaboração, mas estratégias utilizadas para mostrar ao entorno a existência do filho que morreu, para buscar a validação de seu sofrimento. Pela arte, conseguem que outros testemunhem a sua existência e, dessa forma, objetalizam sua perda, tornando-a mais concreta e mais acessível aos processos do luto.

Winnicott (1959/1975) afirma que a criatividade é a base do viver saudável, que é inclusive ela que faz com que a vida valha a pena ser vivida, trazendo um "colorido de toda a atitude com relação à realidade externa" (p. 95). O autor relaciona a possibilidade de viver criativamente com a qualidade do ambiente recebida no início da vida. Com base na teoria winnicottiana sobre a criatividade, permitimo-nos pensar no trabalho de luto vinculado à possibilidade de realizar algo criativo, com o objetivo de resgatar a sensação de que a vida vale 
a pena ser vivida. Em contraste, ajustar-se ou adaptar-se à perda de forma submissa constitui um estado que não pode ser considerado saudável. Winnicott (1959/1975) aponta que, em casos graves de submissão, tudo o que importa permanece oculto e não manifesta qualquer sinal de sua existência.

Romão-Dias (2007) nos lembra que a criatividade é um conceito que Winnicott aproxima aos de espaço potencial e do brincar. Por dizer respeito à saúde e à vontade de viver, a criatividade é fundamental, não só nos estágios iniciais da vida, mas por toda a vida do indivíduo. Portanto, segundo a teoria winnicottiana, para que haja saúde e vontade de viver, é essencial a manutenção do brincar e da criatividade durante toda a vida, inclusive nos percalços de sua existência.

No primeiro capítulo desta dissertação já discorremos sobre o espaço potencial, ideia desenvolvida por Winnicott (1951/1975) que se refere a um espaço intermediário entre o objetivo e o subjetivo. Retomamos o conceito, pois é justamente onde o autor localiza a experiência criativa. Esta visão refere-se a um espaço que não é dentro e, ao mesmo tempo, não é fora, e assinala que o objeto deve se apresentar para, paradoxalmente, ser criado. Para Winnicott (1959/1975), o viver criativo se constitui na capacidade de transitar entre o dentro e o fora, abandonar-se a estados não integrados, com a confiança de que é possível a reintegração. Acreditamos que esta confiança possibilitará uma construção psíquica que não será meramente adaptativa. De acordo com a história precoce e singular de cada indivíduo, este contará com uma herança mais ou menos favorável para usufruir dessa confiança no ambiente e, portanto, da capacidade de criar. Para Winnicott (1959/1975), só podemos pensar num viver criativo levando em conta o meio ambiente.

Algumas pessoas, após algum tempo da perda, escrevem livros ou poesias ${ }^{8}$ com base em sua experiência, outras fazem pinturas e/ou artesanatos. Frida Kahlo, renomada artista mexicana, pintou quadros chocantes ligando as cenas pintadas ao trauma que viveu em abortos repetidos que sofreu. Eric Clapton compôs a emocionante e célebre canção Tears in Heaven após a morte de seu filho, onde questiona se seu filho poderia lhe reconhecer no paraíso.

\footnotetext{
${ }^{8}$ A título de exemplo, a poesia "Maternidade compartilhada" de Larissa Lupi, que serve de epígrafe desta dissertação.
} 
Mas não é apenas dessa forma que a criatividade pode aparecer. Vale ressaltar, junto a Winnicott (1959/1975), que a criatividade não pode ser confundida com a arte criativa, pois esta requer um dom especial e, por isso, é restrita a poucos. Apesar do viver criativo requerer um olhar novo, não requer algo mirabolante. Não é qualquer pessoa que tem a capacidade de compor como Eric Clapton ou de pintar como Frida Kahlo. Sobre isso, Winnicott argumenta que:

(...) para uma existência criativa não precisamos ter nenhum talento especial. Trata-se de uma necessidade universal, de uma experiência universal, e mesmo os esquizofrênicos retraídos e aprisionados ao leito podem estar vivendo criativamente uma atividade mental secreta e, portanto, em certo sentido, feliz. (WINNICOTT, 1999, p. 28)

Também nos cabe ressaltar que, mesmo quando há uma criação pela arte, não é certo que represente um trabalho de subjetivação, podendo às vezes representar uma tentativa de ligação elaborativa sem eficiência simbólica. Para Outeiral e Moura (2002), alguns artistas podem realizar verdadeiras obras de arte com valor cultural inquestionável, mas não refletir seu verdadeiro self e apontar prejuízos na capacidade de transitar com confiança entre o dentro e o fora. Para esses autores, a obra de arte pode se tornar uma "busca desesperada de um self integrado e não o reflexo de uma integração" (p. 9).

Pais enlutados que não consigam responder com alguma criatividade à perda dificilmente conseguirão retomar o desejo de viver. Mas como brincar ou agir criativamente após a morte de um filho que vinha sendo sonhado? Mesmo supondo que esses pais tenham tido um ambiente facilitador na infância e que tenham usufruído de uma mãe suficientemente boa, ainda assim, diante de tamanha adversidade, poderão se sentir invadidos pelo ambiente atual e não conseguir agir sobre ele, podendo apresentar muitas dificuldades de prosseguir seu trabalho de luto e reaver o colorido do mundo externo. Tudo isso nos faz pensar que será essencial que esses pais sejam apoiados pelo ambiente que os cerca na busca de um espaço potencial, de modo que possam procurar criar novas formas de viver e mudar a forma de olhar a situação vivida.

Nesse momento, é essencial pontuarmos que Winnicott (1962/1990) sugeriu que a psicanálise e a psicoterapia são práticas clínicas que se inscrevem em um espaço potencial e transicional, estabelecido entre o analista e o 
analisando, ou entre o psicoterapeuta e o paciente, e, portanto, envolvem as experiências de sonhar e de brincar. O autor afirma que ele, enquanto analista, possui algumas características de um fenômeno de transição, uma vez que, embora represente o princípio da realidade, nem por isso deixa de ser objeto subjetivo para o paciente. Assim, psicoterapia ou análise podem auxiliar na busca de uma resposta criativa, mas deixaremos essa apreciação para o final deste capítulo.

No momento, nos deteremos nas vantagens obtidas quando uma narrativa sobre a experiência vivenciada é possível. Entendemos o narrar como a possibilidade de se contar uma experiência, sendo ao mesmo tempo pessoal e transgeracional, e que atravessa as gerações na humanidade (SAFRA, 2006). Ao narrarmos uma situação, buscamos compartilhar uma experiência de vida, tornando-a presente. Safra (2006) destaca a questão da experiência, pois observa que na atualidade existe uma crescente dificuldade das pessoas em se autorizarem a ter uma experiência. Para que uma pessoa possa experimentar e narrar, ela precisa estar suficientemente sustentada e reconhecida pela sociedade. Nesse sentido, todo desenraizamento produz uma fratura nessas condições.

Como vimos, no luto pelo feto, normalmente os pais não têm uma boa sustentação por parte do entorno, tampouco contam com condições internas para assimilar o ocorrido (já que, especialmente a mãe, encontra-se num estado de regressão narcísica). O não reconhecimento de sua dor, assim como a descaracterização de sua perda, deixam os pais desenraizados, sem a possibilidade de compartilhar o que viveram.

Safra (2006) observa que o mundo na atualidade apresenta uma temporalidade cada vez mais acelerada, o que dificulta a experiência, já que a experiência é o tempo da demora. Frequentemente, após uma perda fetal, o primeiro questionamento dos pais à equipe de saúde é sobre o tempo que poderão "tentar outra vez". Existe uma pressa e um medo do passar do tempo que contribuem para a não elaboração do ocorrido. Para este autor, o narrar enquanto possibilidade do experimentar e do compartilhar está se extinguindo. Algumas formas de adoecimentos atuais ligadas à impossibilidade narrativa estão cada vez mais comuns, como a sensação de não pertencimento (a pessoa não se sente inserida em nenhum grupo), a ausência de si mesmo (falso self), isolamento no qual a pessoa não consegue estabelecer uma comunicação efetiva com ninguém 
etc. Diante das dificuldades para instauração do trabalho de luto, ou de uma melancolia já estabelecida, parece haver um anseio pelo encontro com um outro que de alguma maneira possibilite a oportunidade de pertencer e de comunicar.

As mães que perderam seus bebês antes de nascerem parecem realmente ter um local de pertencimento confuso, sua identificação com o grupo de mães é frágil. Se perguntarmos para uma dessas mães se ela sente-se como mãe, notamos ser comum que ela não se sinta à vontade com a pergunta e mesmo que não consiga respondê-la, pois ao mesmo tempo em que considera que é mãe, por não ter filho vivo não seria uma "mãe em pleno sentido" - a menos que possua outros filhos.

O "narrar" daria condições a essas mulheres para que se apropriassem de suas experiências, mas muitas vezes isto não é possível. Esses pais podem ser lançados à solidão, não conseguindo estabelecer comunicações significativas com qualquer outra pessoa, nem mesmo entre o próprio casal. A clínica com pais que sofreram um óbito fetal, concebida nessa perspectiva, pode ser muito enriquecida, no sentido de trabalhar com a intenção de possibilitar uma narrativa.

Outro espaço que tem se revelado como promissor para expressão criativa diante do luto é a internet. Nesse sentido, Romão-Dias (2007) apresenta a ideia de que a internet, para alguns sujeitos, pode servir como um espaço potencial. Desta forma, seria um local intermediário, diferente da realidade externa e diferente do mundo interno e, portanto, um espaço para o brincar criativo, tal qual Winnicott o concebeu.

\subsection{A virtualidade da internet}

Ao iniciarmos o estudo sobre o luto fetal, nos chamou fortemente a atenção o contraste entre o quão pouco se falava abertamente sobre essa temática e a grande quantidade de vídeos e páginas na internet dedicados a esses bebês que não nasceram vivos. Existem muitas páginas no Facebook $^{9}$, nas quais, especialmente as mulheres, criam uma rede de apoio, dividindo tanto angústias e recordações como estratégias de enfrentamento da dor. Costuma-se incentivar a elaboração de uma narrativa, para que contem sobre o que vivenciaram, o que

\footnotetext{
${ }^{9}$ Site e serviço de rede social criado em 2004, na qual usuários criam perfis que contém fotos e listas de interesses pessoais, trocando mensagens privadas e públicas entre si e participantes de grupos de amigos.
} 
pode ter um papel importante na vinculação da experiência com o mundo da linguagem e pode ser, a nosso ver, uma forma de expressão criativa a partir de seus sofrimentos.

"Do luto à luta", "Precisamos falar sobre isso", "Grupo Sobreviver", "Mães de anjo", "Mães sem nome" e "Mães de estrelas" são alguns dos grupos que estão na internet, buscando um espaço com o qual essas famílias possam se identificar e validar o sofrimento que atravessam. Os nomes das páginas citadas nos trazem a questão do abstrato da perda e da luta que é encará-la e falar sobre ela.

Muitos vídeos são carregados no Youtube ${ }^{10}$, contando a história da gestação, normalmente com fotos e uma música ao fundo. Esses vídeos nos parecem ser uma tentativa dos pais de "mostrar ao mundo" e a si mesmos que seu bebê existiu, mesmo que só para eles. Com essa estratégia, podem se aproximar de uma objetalização da perda. Ao fazer o vídeo, fica mais claro que o que perderam foi um filho real, com um nome próprio e uma história, ainda que curta. Além disso, podem encontrar um grupo de pertencimento no qual poderá ser possível a identificação com sentimentos comuns.

Conforme as ideias de Safra (2006), ao encontrar-se em um grupo de pertença, poderão ter a possibilidade de experimentar e compartilhar. Cria-se um espaço entre os "pais" e os "não pais", que frequentemente são chamados de "pais de anjos", fazendo referência aos pais que perderam seus bebês antes ou logo após o nascimento. Nomeia-se e valida-se a existência de um espaço singular, com fronteiras menos rígidas, onde podem falar do que lhes afligem subjetiva e objetivamente.

Missonnier (2015) chama atenção para o início do surgimento de um grande número de vídeos nas redes sociais postados por pais enlutados a partir de 2005. O autor observa que os vídeos podem se revelar uma tentativa de subjetivação criativa, entremeada pela exposição de seu sofrimento. Esses vídeos e relatos de histórias na internet não têm uma significação a priori, não são criativos ou patológicos em si mesmos. Mesmo que não simbolizem um espaço de elaboração, mas se mostrem como uma repetição traumática, ainda assim podem funcionar como um pedido de ajuda e uma quebra do silêncio que se instaura em

\footnotetext{
${ }^{10}$ Site de carregamento e compartilhamento de vídeos em formato digital, enviados por seus usuários através da internet, fundado em 2005.
} 
torno dessa morte. Essas práticas oferecem uma oportunidade aos pais de construir a representação de sua realidade psíquica, e também dão às pessoas próximas a oportunidade de entenderem a sua dor e se expressarem através de mensagens que são expostas publicamente após os vídeos e relatos.

Em nossa cultura, muito se destaca a dificuldade que temos em falar sobre a morte. Muitos autores falam que se trata mesmo de um tabu, especialmente quando a morte está referida à infância, "invertendo a ordem natural da vida". Ao longo deste trabalho, vimos muitas dificuldades com as quais os pais são confrontados ao lidar com a morte de seu bebê. E, então, pensamos agora porque a internet se mostra como um local mais disponível para expressar essa vivência.

Os pais perderam uma promessa de filho, uma promessa de paternidade e maternidade. Morreu um filho que não representava ainda um ser totalmente independente deles e de suas projeções, um filho ainda virtual. Nos chama atenção a convergência entre o virtual deste filho e o virtual da internet, e assim somos lançados a pensar novamente sobre o espaço transicional formulado por Winnicott. O que percebemos é que algumas pessoas conseguem utilizar a internet como um espaço potencial (ROMÃO-DIAS, 2007), como um local diferente da realidade externa e diferente do mundo interno e, por isso, possivelmente mais fácil de expor esse bebê que também fazia parte dessa dimensão intermediária.

O espaço potencial foi definido por Winnicott (1951/1975) como uma área de repouso onde não seria preciso manter separadas as realidades externa e interna, onde o teste de realidade não é convocado e pode-se experimentar uma ilusão entre o subjetivo e aquilo que é objetivamente percebido. Nesse sentido, o espaço potencial está livre das exigências da realidade, sem, ao mesmo tempo, estar sob o total controle do mundo interno. Winnicott afirma que, ainda que o espaço potencial se constitua nos primeiros estágios da vida de um ser humano, ele não perde sua função ao longo da vida. De acordo com o autor:

De todo indivíduo que chegou ao estádio de ser uma unidade, com uma membrana limitadora e um exterior e um interior, pode-se dizer que existe uma realidade interna para esse indivíduo, um mundo interno que pode ser rico ou pobre, estar em paz ou em guerra. Minha reivindicação é a de que, se existe necessidade desse enunciado duplo, há também a de um triplo: a terceira parte da vida de um ser humano, parte que não podemos ignorar, constitui uma área intermediária de experimentação, para a qual contribuem tanto a realidade interna quanto a vida externa. Trata-se de uma área que não é disputada, porque nenhuma reivindicação é feita em seu nome, exceto que ela exista como lugar de repouso 
para o indivíduo empenhado na perpétua tarefa humana de manter as realidades interna e externa separadas, ainda que inter-relacionadas. (WINNICOTT, $1951 / 1975$, p. 15)

Pensamos que a internet pode representar esse espaço de repouso, onde a ilusão é permitida, sem, no entanto, desconsiderar totalmente a realidade externa. Assim, como espaço potencial, a expressão desses vídeos e histórias na rede virtual permite certo alívio para os pais, que não precisam estar entre as exigências da realidade e as exigências de seu mundo interno. A nosso ver, um exemplo disso é a prática crescente de famílias que publicam na rede textos como se estivessem falando com seu filho que não nasceu, jurando amor eterno e garantindo seu espaço na família. Outra prática que vemos é a postagem de fotos de ultrassom e mesmo fotos onde inserem digitalmente uma sombra do filho que morreu junto ao restante da família, como se compusessem a família de forma mística.

Reconhecemos a grande potencialidade que a internet pode representar no auxílio à elaboração de uma perda tão significativa em um momento extremamente delicado. Porém, não podemos deixar de pontuar que, para constituir um espaço de construção psíquica, tudo dependerá da forma como o sujeito pode utilizar esse espaço. Romão-Dias (2007) afirma que, para os sujeitos que utilizam a internet apenas com fins de comunicação, que não brincam na internet, ela não irá lhes abstrair da realidade externa, não os deixará absortos e não será, portanto, um espaço "neutro". Dessa forma, a internet não poderá lhes servir como um espaço potencial. Assim sendo, a internet poderá criar uma falsa realidade que pode confundir os sujeitos e levá-los a um uso solitário e patológico.

\subsection{Possibilidades terapêuticas}

Além das possibilidades apontadas pela internet, uma grande variedade de trabalhos terapêuticos pode ser proposta para as mães, os pais e os casais que perderam seus bebês, quando a experiência vivenciada foi desorganizadora e de muita violência. Sessões terapêuticas antes e após a interrupção médica, atendimentos individualizados ou em grupo durante a próxima gravidez e após o nascimento do outro filho, espaços mais reflexivos ou de orientação. Enfim, muitas possibilidades podem ser consideradas e até evoluírem para um 
encaminhamento a atendimento psicanalítico. Como ressaltamos anteriormente, o espaço da psicoterapia e da psicanálise já indica uma possibilidade de ativar o espaço potencial que será benéfico para o sujeito em sua busca por uma mudança subjetiva.

Diante desse momento de crise e radical silêncio que o luto fetal costuma instaurar, a psicanálise poderá auxiliar, procurando lançar luz sobre o que ocorre nesta perda, através de intervenções clínicas junto a essas famílias. Acreditamos, como já indicamos, que o acompanhamento psicanalítico pode constituir um espaço importante para propiciar uma elaboração psíquica da experiência vivenciada, uma vez que o trabalho do analista almeja justamente que essa morte não seja escamoteada. Quanto mais o bebê for investido psiquicamente e chamado pelo nome que seus pais escolheram, mais lugar será dado às circunstâncias de sua existência (ainda que apenas intrauterina) e de sua morte e, assim, mais os pais estarão em condição de fazer seu luto por esse bebê (MATHELIN, 1999).

A perda fetal pode representar uma grande ferida narcísica para os pais, especialmente para a mãe, que sente a morte incrustrada em seu próprio corpo. Nesse sentido, os modelos narcísicos ou melancólicos explicam melhor (do que o modelo histérico) o cenário que nos é apresentado. Pinheiro (2012) descreve esse modelo, característico da melancolia, como típico de pacientes com enorme angústia que os assalta e cuja origem desconhecem, além de possuírem grande dificuldade de se projetar no futuro, sendo muito críticos, sobretudo consigo mesmos. Esses pacientes precisam matar uma parte de si mesmos para prosseguir em seu trabalho de luto e, muitas vezes, são lançados em um estado de fragilidade de sua existência, questionando o sentido dos seus sentimentos e trazendo uma enorme angústia. Pensamos que essa clínica irá remeter ao traumatismo, que escapa à representação e ao sexual, referindo-se ao acontecimento impensável, mais próximo ao desamparo inicial da vida.

No sentido de favorecer a introjeção da experiência vivenciada, possibilitando a entrada no processo de luto, não apenas o acompanhamento psicanalítico individual nos parece profícuo, mas acreditamos que outra forma eficaz de se trabalhar com essas psiques cindidas seria através de um grupo terapêutico. A capacidade de colocar o trauma em palavras, construindo uma narrativa, será um momento importante na elaboração desses traumatismos. 
Pensamos que o trabalho em grupo, em um lugar onde os membros se sintam efetivamente pertencentes e que possam experimentar seus verdadeiros sentimentos, constitui também uma opção bastante eficaz. $\mathrm{O}$ trabalho em grupo pode auxiliar na elaboração psíquica ao redor de temas sobre maternidade e paternidade interrompidas, pode funcionar como espaço acessível à expressão de lutas internas e ainda assegurar o reconhecimento e validação das questões levantadas por um grupo que compreende e acolhe suas questões. Muitas mulheres que sofreram perdas fetais alimentam um grande ódio pelo mundo, por outras mulheres grávidas e até por suas próprias mães. Muitas vezes se culpam e se envergonham por esses sentimentos. Com o auxílio do grupo, ao perceber que outras mulheres se sentem da mesma forma, podem validar esse sentimento e reconhecê-lo, podendo falar sobre isso.

Soubieux e Caillaud (2015) relatam suas experiências com grupos de mães enlutadas em uma instituição hospitalar na França. As autoras apontam para a importância da circulação do discurso entre as mulheres, ressaltando que as respostas que elas esperam são aquelas das outras mães. Observam que, em um primeiro momento, é privilegiado um tempo de história que se repete, às vezes de sessão em sessão, até que ocorre uma renúncia, operando-se um deslocamento do trauma face à história de outra participante ou por efeito da aceitação da perda. Algo da história individual de cada uma pode relacionar-se às histórias das outras, com a história do grupo.

Soubieux e Caillaud (2015) refletem ainda sobre o papel dos analistas que trabalham com esses grupos de mães, e sugerem que devemos renunciar as interpretações imediatas dos conteúdos, dando ênfase às figuras do estrangeiro familiar, com neutralidade e implicação. Dessa forma, em grupo, as mulheres não se sentem impedidas de pensar e procurar saber mais sobre o que sentem. Podem investir em diálogos que dizem respeito à violência e ao medo da perda. A proposta do grupo seria possibilitar que a violência se exprima simbolicamente, acessando fantasmas e possíveis ansiedades geradas.

Acreditamos que o dispositivo grupal permite um tempo de elaboração importante. Cada membro do grupo pode ter seu tempo específico até que consiga dividir sua história, colocando-a numa narrativa. Porém, mesmo no silêncio, acreditamos haver um trabalho elaborativo diante da dor e do não dizível, 
permitindo que o sujeito tenha a possibilidade de escutar os outros membros do grupo.

Soubieux e Caillaud (2015) citam como objetivos do grupo terapêutico: “organizar a maré pulsional, resistir a impossível vingança que preside no trabalho de luto perinatal e acolher os sentimentos poderosos de injustiça e desigualdade do destino face à crueldade da vida e da sua própria crueldade" (p. 28). Esse, para essas autoras, seria o trabalho de elaboração do grupo. Com paciência e tolerância, o ódio e a vontade de destruição poderão ser aceitos.

Soubieux (2015) reflete que o grupo terapêutico pode auxiliar também no processo de não conservar a criança morta como único objeto de amor e ajudar a lutar contra o "apagamento das imagens". As lembranças do bebê estão muitas vezes ligadas ao inconsciente, abrigando ódio e desejos mortíferos. Numa tentativa de escamotear, esses poderosos sofrimentos correm o risco de terem suas lembranças esmaecidas. É nesse sentido que o grupo, ao permitir a expressão dos verdadeiros sentimentos, favorece a conservação das lembranças. No grupo, a raiva pode ser assumida e depositada através do espaço que possibilita o discurso. Sem sentirem-se pressionadas a esconder seus sentimentos hostis, as lembranças do bebê (atreladas a esses sentimentos até então obscuros) não serão atraídas para o inconsciente.

Para trabalharmos com famílias enlutadas, seja de forma individual ou em grupo, parece-nos fundamental um olhar atento para a importância de favorecer a expressão de palavras que possam ser ligadas ao trauma experienciado. Da mesma forma, faz-se necessário acolher esses diálogos e sentimentos, às vezes violentos e destrutivos. Soubieux e Caillaud (2015) salientam que os analistas tem um papel extremamente importante nesse processo. Afirmam que nós devemos nos deixar afetar pelos diálogos, sem pensar, e somente depois pensar no que nos afetou. Devemos aceitar sermos utilizados como um objeto maleável.

O conceito de objeto maleável é um conceito pensado por Milner e aprofundado por Roussillon (2008) em complemento às ideias de Winnicott sobre objetos transicionais, uma vez que trabalha sobre as qualidades dos adultos (ou dos dispositivos terapêuticos) que vão permitir à criança (ou ao paciente) se diferenciar.

Winnicott foi um dos primeiros autores a lançar atenção sobre a utilização psíquica particular que as crianças podiam fazer de certos objetos em seu meio 
ambiente e, então, conferiu a esses objetos um verdadeiro estatuto significante (ROUSSILLON, 2008). Através dos estudos relacionados ao objeto transicional de Winnicott (1951), se reconhece a importância de um certo número de objetos para possibilitar uma diferenciação da mãe ou das pessoas presentes na função materna, de forma suave e não traumática. Mas, a proposta de um objeto maleável traz uma nova reflexão a respeito das qualidades dos adultos que podem permitir a criança se destacar mais ou menos facilmente. Pensar no objeto maleável é uma maneira de descrever certa relação de objeto, na qual esperamos que ela guarde no fundo a memória do que se passou, mas que volte a ser como antes, sem podermos lhe estragar e sem o risco de vingança. A maleabilidade seria, portanto, uma característica que confere aos objetos sua capacidade de separabilidade, ou seja, de separar-se de forma gradual e não traumática.

Roussillon (2008) propõe o entendimento da função do objeto maleável em comparação com uma massa de modelar. A massa de modelar não representa nada em si mesma, não tem forma determinada, mas pode assumir diversas formas, sem oferecer resistência. Está sempre disponível para o uso, não pode ser destruída, conserva a forma dada pela criança até que decida usá-la novamente. Quando a massa é deixada de lado, conserva o traço da manipulação, mas muito suavemente retoma sua forma inicial e mesmo se apertada de maneira intensa, com amor ou raiva, não poderá ser estragada ou destruída.

Ou seja, as características deste objeto maleável que é a massa de modelar, se aproximam da noção de maleabilidade dos objetos primordiais ou dos dispositivos terapêuticos. Golse (2003) pontua que nossos instrumentos terapêuticos devem ser suficientemente maleáveis, pensados como um espaço onde o paciente possa imprimir alguma coisa pessoal, deixar um traço próprio, jogar toda sua força de amor ou de agressividade, sem destruí-lo e sem que apresente possibilidade de vingança. Ou seja, uma das principais qualidades dos dispositivos deverá ser a indestrutibilidade, sua capacidade de sobreviver. A presença do terapeuta é a garantia da continuidade de ser e da própria vida, da dinâmica e da eficácia terapêutica.

Nesse contexto, é essencial retomar outro conceito muito importante para o pensamento analítico: o conceito de holding, desenvolvido por Winnicott (1960/1990). Essa reflexão se faz crucial por acreditarmos que sua função será central nesta clínica. O psicanalista inglês define holding como o primeiro 
ambiente do bebê, um suporte confiável que deve existir desde o nascimento, para que este possa desenvolver-se em direção à integração e ter preservada sua experiência de continuidade. Para tal objetivo, o bebê dever ser cuidadosamente sustentado pelo outro em uma etapa da vida na qual é ainda incapaz de executar movimentos suficientemente autônomos, que envolve diversos comportamentos e atitudes do outro, realizados com o objetivo de regrar e estabilizar as necessidades fisiológicas e emocionais da criança. Esse conceito, apesar de referir-se a um cuidado físico localizado ao início da vida, permite amplos desdobramentos teórico-clínicos.

Ogden (2004) o compreende como um conceito ontológico utilizado para explorar as qualidades específicas da experiência de estar vivo em diferentes estágios do desenvolvimento. O holding estaria relacionado com o ser e sua relação com o tempo. Uma das principais funções do holding inicial da mãe inclui o isolamento do bebê em seu estado de "continuar a ser", absorvendo o impacto do tempo, transformando para o bebê o impacto da alteridade do tempo e criando em seu lugar a ilusão de um mundo no qual o tempo é mediado quase totalmente nos termos dos ritmos físicos e psicológicos do bebê. O holding inicial do bebê pela mãe representa uma anulação de si própria em seu esforço inconsciente para não atrapalhar o bebê, assim promovendo um ambiente propício para o seu filho, para que comecem a se evidenciar suas tendências maturacionais e para que possa experimentar um movimento espontâneo (OGDEN, 2004). À medida que o bebê cresce, a função do holding muda para dar sustentação, ao longo do tempo, aos modos de estar vivo mais relacionados ao objeto.

Segundo Ogden (2004), uma dessas formas posteriores de holding envolve a provisão de um "lugar" (um estado psicológico) no qual o bebê (ou o paciente) possa se organizar. O analista deve ser capaz de promover esse lugar para o analisando, onde ele possa sustentar sua existência e se organizar, ou seja, prover aquele lugar no qual o paciente poderá sentir confiança. O que podemos concluir junto a Winnicott (1960/1990) é que o holding pode ser entendido como dispositivo analítico que visa o estabelecimento de uma provisão ambiental capaz de fornecer o suporte necessário para a integração de experiências vividas.

Diante da violência que sofreram por não poder colocar seus filhos no mundo, de ter visto sua criança morrer inerte e por envergonharem-se de seus ódios, ainda sofrem a violência do não reconhecimento da perda pelo entorno e 
pela sociedade, desvalorizando sua dor. Precisam ser acolhidos por profissionais que suportem essa agressividade e sobrevivam a ela, e que forneçam um holding físico e emocional, estabelecendo um espaço psicológico que sustente a sua existência. Se soubermos acompanhar essas famílias, se pudermos lhes ajudar a sobreviver e encontrar vida em si, poderemos ser surpreendidos por sua criatividade psíquica e por movimentos de crescimento psíquico.

A fim de refletir sobre o processo que almejamos com o acompanhamento psicanalítico com pais enlutados, trazemos o conceito de continente-contido de Bion. Esse conceito trata da interação dinâmica entre pensamentos predominantemente inconscientes (o contido) e a capacidade de sonhar e pensar esses pensamentos (o continente). Bion (1962) nos apresenta a ideia de que a personalidade humana tem potencial para um conjunto de operações mentais que podem realizar um trabalho psicológico consciente e inconsciente sobre a experiência emocional. Esse processo tem como resultado um crescimento psíquico.

O continente é a capacidade para o trabalho psicológico de sonhar, operando juntamente com a capacidade de pensamento pré-consciente (devaneio) e a capacidade para pensamento de processo secundário consciente. O contido refere-se aos pensamentos e sentimentos que estão no processo de serem derivados de nossa experiência emocional vivida. Bion (1962) destaca que os mais elementares pensamentos que constituem o contido são as "impressões sensórias brutas relacionadas a uma experiência emocional" (p. 18), chamadas por ele de elementos beta. Esses pensamentos mais básicos, que não podem ser ligados entre si, constituem, como esclarece Ogden (2004) sobre a leitura de Bion, a única conexão entre a mente e nossa experiência emocional vivida no mundo da realidade externa. Esses pensamentos (elementos-beta) são transformados pela função-alfa em elementos da experiência, chamados elementos-alfa, que podem ser ligados no processo de sonhar, pensar e recordar. Quando o relacionamento de continente e contido é de mútuo benefício e sem dano a nenhum dos dois, o crescimento ocorre tanto no continente, como no contido.

Em relação ao continente, o crescimento envolve um aumento da capacidade de sonhar a própria experiência, isto é, a capacidade de realizar trabalho psicológico. (...) $\mathrm{O}$ crescimento do contido se reflete na expansão da extensão e profundidade dos pensamentos e sentimentos que somos capazes de derivar de nossa 
experiência emocional. (...) em outras palavras, o contido cresce ao tornar-se mais capaz de abarcar a plena complexidade da situação emocional da qual ele deriva. (OGDEN, 2004, p. 132)

O conceito de Bion sobre o "continente-contido" expande o foco de atenção no setting analítico para além da exploração do conflito, para além das questões edípicas. Para a psicanálise, mais precioso do que facilitar a resolução de conflitos é a interação dinâmica entre pensamento e sentimentos derivados da experiência emocional vivida (o contido) e a capacidade de sonhar e pensar esses pensamentos (o continente).

O objetivo primordial da psicanálise (...) é facilitar o crescimento do continentecontido. (...) A tarefa do analista é criar condições no setting analítico que permitam o mútuo crescimento do continente e do contido. À medida que o analisando desenvolve a capacidade de produzir uma extensão e profundidade mais completa de pensamentos e sentimentos em resposta a sua experiência (passada e presente) e sonhar esses pensamentos (fazer trabalho psicológico com eles), ele não precisa mais da ajuda do analista para sonhar sua experiência. (OGDEN, 2004, p. 133).

Ogden (2004) compreende que uma falha na função-alfa significa que o paciente não é capaz de sonhar. Se uma pessoa é incapaz de transformar impressões sensórias brutas em elementos inconscientes da experiência que possam ser ligados, ela é incapaz de sonhar, seja durante o sono ou em vigília. Ogden nos diz que, na medida em que a pessoa é incapaz de sonhar sua experiência emocional, o indivíduo é incapaz de mudar ou de crescer.

Bion (1962) propõe uma metáfora do relacionamento mãe-bebê inspirado no conceito de identificação projetiva de Melanie Klein: o bebê projeta na sua mãe a experiência emocional que ele é incapaz de processar sozinho, já que sua função-alfa ainda é rudimentar. A mãe, quando saudável, realiza o trabalho psicológico inconsciente de sonhar a experiência insuportável do bebê e a disponibiliza para ele de uma forma que seja possível que ele mesmo sonhe sua experiência. Bion salienta que uma mãe que é incapaz de estar emocionalmente disponível para o bebê devolve para ele seus pensamentos intoleráveis sem uma explicação.

Pensando nessa metáfora, Ogden (2004) supõe que, tal como o bebê precisa da ajuda da mãe para sonhar, alguns pacientes buscam ajuda na análise para sonharem sua experiência não sonhada. Nesse sentido, os devaneios do 
analista são centrais ao processo analítico, uma vez que constituem uma via de acesso pela qual o analista participa no sonhar dos sonhos que o paciente é incapaz de sonhar sozinho. Analista e paciente, juntos na análise, têm como objetivo gerar condições para que o analisando, com a participação do analista, possa tornar-se mais capaz de sonhar.

Nesse sentido, Winnicott (1962/1990) nos conforta com sua ideia de que em alguns casos é importante uma mudança clínica, ao invés de se realizar uma análise padrão. Nessa análise modificada, o analista é convocado a adotar uma postura diferente, menos interpretativa e mais empática. O conceito de Ogden (2004) a respeito do terceiro analítico nos ajuda a compreender melhor essa posição. Ogden concebe a situação analítica composta por três sujeitos que interagem inconscientemente entre si: o paciente, o analista e o que chamou de terceiro analítico. Este último seria criado pela interação inconsciente do paciente e do analista, sendo "tanto o analista e o paciente quanto nenhum deles" (p. 23). O terceiro analítico se forma no setting analítico, construído no "campo de forças emocionais criado pela interação do inconsciente do paciente e do analista" (p. 23).

O autor observa que esse terceiro sujeito surgido no encontro da análise é um sujeito construído conjunta, mas assimetricamente. As tarefas do analista e do analisando são diferentes. A maturidade emocional do analista deve estar além da maturidade emocional do analisando nas áreas de experiência mais problemáticas para o paciente. $\mathrm{O}$ analista precisa ser capaz de crescer emocionalmente como consequência de sua experiência com o paciente:

É tarefa do analista como sujeito separado (no decorrer do tempo) tornar-se cônscio das experiências no e do terceiro analítico e simbolizá-las verbalmente para si mesmo. (...) O analista esta tentando envolver o paciente em uma forma de pensamento consciente que pode funcionar em consonância com o trabalho inconsciente do sonhar do paciente e facilitá-lo. (OGDEN, 2004, p. 23)

O que observamos com os pacientes enlutados é que, frequentemente, por conta do trauma sofrido, a interação dinâmica entre contido e continente encontrase prejudicada, havendo uma falha na função-alfa. Por isso, o trabalho dos três sujeitos da análise deve se dar no sentido de facilitar o crescimento mútuo dos pensamentos inconscientes e, ao mesmo tempo, da capacidade de sonhar e pensar esses pensamentos. Para esses pacientes, seja no acompanhamento individual, seja 
na abordagem grupal, é importante que estabeleçam uma relação entre aspectos pré-conscientes da mente com pensamentos e sentimentos inconscientes. Assim, poderão realizar um trabalho psíquico, lidar com a complexidade da sua situação emocional, olhar para a experiência vivida e compreendê-la melhor.

Parece-nos claro que a clínica com pais enlutados deverá ser um trabalho capaz de contemplar os impasses clínicos e a busca cuidadosa de recursos técnicos, a fim de possibilitar um espaço em que o paciente possa sentir-se menos despedaçado e ser capaz de sonhar suas experiências. Será importante um papel criativo do analista, colocando seu aparelho psíquico disponível para o paciente durante as sessões, sendo capaz de sonhar o inconsciente do outro. 


\section{Considerações finais}

A maternidade e a paternidade são consideradas uma das experiências mais marcantes no desenvolvimento de homens e mulheres, uma vez que em nossa sociedade as crianças ocupam lugar de destaque na família e na vida social. Vimos como a gestação inaugura uma fase de transformações em direção à construção da parentalidade que envolve um conjunto de remanejamentos psíquicos e afetivos. Após nossas reflexões, consideramos que a interrupção deste processo pela morte do bebê (feto ou embrião) adquire inquestionável efeito destrutivo para os pais, pois exige um trabalho psíquico muito intenso, na contramão do que estavam se preparando. A morte do filho antes de seu nascimento rompe com a "ordem natural da vida", inverte as expectativas de perdas presumidas ao longo da vida, onde os mais velhos deveriam morrer primeiro. Com o bebê morre também os sonhos, as expectativas e esperanças depositadas nos bebês.

Ao longo deste trabalho, procuramos ressaltar a singularidade e as vicissitudes suscitadas por uma morte fetal. Destacamos que, como todo luto, o luto pelo feto é um processo lento e doloroso que exige uma renúncia ao objeto de amor perdido. Observamos, no entanto, que essa perda comporta questões relevantes e distintas de outros lutos experimentados por perdas de diferente natureza. Destacamos ao longo desta dissertação: o estatuto confuso do feto, que ainda não constitui um objeto completamente independente de seus pais; o momento de transição em que a morte se dá, operando uma quebra no processo de reorganização psíquica para a parentalização; a indiferença do entorno frente à morte, desvalorizando a perda dos pais; a inversão da chamada "ordem natural das coisas", impondo a morte quando a expectativa é de vida; e, por fim, a localização da morte intimamente ligada ao corpo da mãe.

Nossa reflexão a respeito da natureza do óbito fetal nos levou à questão da virtualidade, evidenciando uma perda que aponta em alguns momentos para algo de uma concretude externa, porém em outros momentos sublinha a perda narcísica. Essa dimensão (virtual) do objeto perdido acarreta uma dificuldade para objetalizar a perda sofrida. O bebê morre justamente no momento em que estava construindo progressivamente o reconhecimento de sua alteridade, que tornaria possível o estabelecimento de uma relação objetal. Existe, durante a gestação, 
uma elaboração objetal progressiva no feto confrontando os pais a um duplo movimento: a busca imaginária pela criança que foram e a busca por construir uma identidade parental. Constatamos, nesse trabalho, que o luto pelo feto comporta um trabalho que é tanto narcísico como objetal, uma vez que fazer o luto do bebê perdido é fazer o luto de partes infantis de si mesmo, de conflitos não resolvidos, das relações idealizadas e também fazer o luto de ser pai e ser mãe. A morte durante a gravidez declara-se como a interrupção de uma promessa, uma vez que o bebê já existia enquanto potencialidade.

A coincidência entre o início da vida com a morte revela-se como um acontecimento demasiadamente difícil de ser inserido no mundo da linguagem e de ser introjetado psiquicamente. Ao longo desta dissertação, pudemos discorrer sobre as dificuldades da sociedade, inclusive dos profissionais de saúde, em incentivar os pais na vivência de seu luto, o que mostra-se como uma tentativa de destituir a perda de significado e de escamotear seu verdadeiro sentido. Nessa perspectiva, consideramos ser importante incentivar os pais a assumir uma postura mais ativa frente à morte do seu filho, podendo escolher, embasados por seu próprio desejo, se querem vê-lo, vesti-lo, tocá-lo, participar de rituais fúnebres e de despedida, desfazer-se dos pertences do filho, etc. Desta forma, poderão ter lembranças que possam ser evocadas e investidas posteriormente em um trabalho de luto.

Freud indicou que o trabalho de luto constitui um processo normal da vida e gradual cuja função é a elaboração e assimilação psíquica da perda, assim como possibilitar a separação do objeto perdido e o reinvestimento em um novo objeto. Neste trabalho seria possível uma identificação histérica, na qual o sujeito se identifica com traços do objeto, mantendo algo do objeto perdido, o que possibilita a aceitação da perda. No entanto, verificamos que a instauração do processo de luto pode ser muito difícil e, mesmo quando for possível, pode passar por um primeiro tempo em que usufrui de uma identificação melancólica para só depois evoluir para sua elaboração. Também concluímos que este trabalho pode retornar muito tempo depois, nas gravidezes posteriores, em datas marcantes relacionadas à morte ou aniversários. Observamos ainda que esse luto pode não se realizar, às vezes não existindo a possibilidade de mudança e de acesso à introjeção e à elaboração psíquica, o que pode acabar levando a vias patológicas. Nestes casos, destacamos a via da melancolia, por acreditarmos que constitui uma 
opção, por vezes, mais disponível aos pais diante da morte do filho por seu caráter narcisista. Porém, cada história sempre implica em algo singular, o que não nos permite apontar tendências universais: o óbito fetal pode incitar diferentes evoluções.

A identificação feita por traços, tal como ocorre nos modelos histéricos, pode não ser uma opção acessível aos pais que perderam seus bebês nessa fase de construção da parentalidade. A identificação com o feto morto é muito difícil, uma vez que ainda não se constitui como um verdadeiro objeto externo, que não existem lembranças a serem evocadas e que a perda pode não ser sentida como real. A representação deste bebê perdido costuma estar fortemente vinculado a uma imagem de um ideal, difícil de ser abdicada. Assim, a libido investida no bebê perdido terá dificuldades de se deslocar para outro objeto, então pode ser recolhida para o próprio eu e servir para estabelecer uma identificação no eu com o objeto abandonado, ou seja, uma identificação melancólica.

Acreditamos ser uma grande contribuição para a clínica e estudo com famílias enlutadas, o conhecimento de que um primeiro tempo do luto fetal pode ser caracterizado por uma identificação melancólica que depois evolua para uma elaboração, podendo constituir uma primeira etapa neste processo (SOUBIEX, 2014). Como vislumbramos, o bebê morre antes de ser possível uma identificação com o objeto, uma apropriação subjetiva, assim os pais podem estabelecer uma identificação melancólica como parte do processo de luto, para que seja possível uma identificação com o objeto, ainda que com o objeto "em bloco". Dessa forma, aos poucos, poderão iniciar um trabalho de reconhecimento da incompletude do objeto de amor, afastá-lo das imagens de ideais, possibilitar o gradual desinvestimento e separação deste.

Procuramos dedicar a parte final desta dissertação para apontar que a introjeção de um acontecimento traumático, como a morte de um bebê esperado, pode ocorrer, desde que os sujeitos envolvidos possam usufruir de espaços intermediários, nos quais seja possível acessar saídas criativas que os permita uma nova visão e associações. Nesse sentido, a história de cada sujeito, com suas primeiras relações objetais e qualidade ambiental, será um importante indicador de saúde, facilitando, ou não, o usufruto de estados de confiança e criatividade, que poderão ser buscados não apenas em uma terapia, mas também na arte e no uso da internet, entre outros. Buscamos, assim, marcar nossa esperança de que 
sempre será possível uma elaboração eficaz, por mais doloroso e lento que possa ser o caminho. Retomando Winnicott (1959/1975) salientamos como a criatividade é a base para um viver saudável e que pode aparecer de diferentes formas, não requer uma produção artística excepcional, mas algo que indique uma tentativa de ligação elaborativa. Destacamos a importância da busca por espaços potenciais, espaço intermediário entre o objetivo e o subjetivo, para impulsionar o sujeito em direção a uma apropriação criativa da experiência vivida, possibilitando novas formas de olhar, narrar e modificar sua experiência, afim de que possa vir a se incluir psiquicamente.

O impacto desta "partida que antecede a chegada", como indicamos no título deste trabalho, abarca toda a família e nos alerta a lançarmos olhares cautelosos a todos os envolvidos, incluindo os profissionais de saúde e demais profissionais que têm contato com tais mortes prematuras. Para finalizar nossas apreciações, gostaríamos de reforçar a importância do trabalho do psicólogo ou psicanalista junto às famílias - seja já nas maternidades e clínicas de ultrassonografia, lhes acompanhando no recebimento do anúncio da morte, possibilitando uma narrativa que lhes permita refletir e verbalizar sobre seus medos e ambivalências; seja lhes auxiliando a priorizar seus desejos em relação aos procedimentos durante e após o parto; ou seja ainda através de acompanhamento psicoterápico ou psicanalítico (em grupo ou individual) após o momento inicial.

Nesses casos, o analista pode ser convocado a uma postura diferente, menos interpretativa e mais empática. Diante da violência que sofreram com a morte do filho, de sua impotência e vergonha de seus sentimentos, essas famílias precisam ser acolhidas por profissionais que sobrevivam a essa agressividade e que forneçam um holding físico e emocional, estabelecendo um espaço psicológico que sustente a sua existência. Ressaltamos a importância do papel criativo do analista na busca cuidadosa de recursos técnicos e permitindo-se adquirir características da maleabilidade, a fim de possibilitar um espaço em que o paciente possa experimentar um sentimento de confiança e buscar um verdadeiro crescimento psíquico.

O trabalho deste profissional, como apontamos no corpo desta dissertação, também será primordial em relação à equipe multidisciplinar que, consciente de sua vivência e importância de sua postura, poderá ajudar as famílias enlutadas de 
forma mais eficaz, diminuindo os obstáculos à vivência do luto, tal como a dificuldade de comprovação da morte, a desvalorização dos sentimentos e desejos dos familiares frente à morte do feto. Pontuamos ser essencial a adoção de um espaço reflexivo no qual os profissionais possam expressar suas angústias relacionadas à morte e validar suas emoções ao invés de sufoca-las.

Reconhecemos que não exploramos questões importantes neste trabalho, como o luto de um gemelar e as implicações de uma gravidez após uma morte fetal. Optamos por não entrar nestes caminhos por acreditarmos implicarem em questões particulares que poderiam nos desviar do objetivo desta dissertação, mas ressaltamos a relevância de serem retomados em trabalhos posteriores. 


\section{Referências bibliográficas}

ABRAHAM, N.; TOROK, M. Luto ou melancolia, introjetar-incorporar. In: ABRAHAM, N.; TOROK, M. A casca e o núcleo. São Paulo: Escuta, 1995 (Trabalho original publicado em 1968).

ARAGÃO, R.O. Narrativas do início da vida: como contar nosso primeiro capítulo? Primórdios, Rio de Janeiro, v. 2, n. 2, p. 73-83, 2012.

BINOTTO, A. Natimorto, aborto e perda perinatal: a morte no lugar do nascimento. In: CASELATO,G. (Org.). Dor silenciosa ou dor silenciada? Perdas e lutos não reconhecidos por enlutados e sociedade. São Paulo: Livro Pleno, 2005. p.35-50.

BION, W. Learning from experience. In: Seven servants. New York, 1962

BRAGA, N.A.; MORSCH, D.S. Quando o bebê morre. In: MOREIRA, M.E.L.; BRAGA, N.A.; MORSCH, D.S. (Orgs.). Quando a vida começa diferente: o bebê e sua família na UTI neonatal. Rio de Janeiro: Fiocruz, 2003. P.157-170.

BRASIL. Ministério da Saúde. Manual de vigilância do óbito infantil e fetal e do Comitê de Prevenção do Óbito Infantil e Fetal. 2. ed. Brasília: Ministério da Saúde, 2009. Disponível em: <http://bvsms.saude.gov.br/bvs/publicacoes/ manual_obito_infantil_fetal_2ed.pdf>. Acesso em 12/02/2016.

Ministério da Saúde. Manual AIDPI neonatal. 3. ed. Brasília: Ministério da Saúde, 2012. Disponível em: <http://bvsms.saude.gov.br/bvs/ publicacoes/manual_aidpi_neonatal_3ed_2012.pdf>. Acesso em 12/02/2016.

BYDLOWSKI, M. O olhar interior da mulher grávida: transparência psíquica e representação do objeto interno. In: CORRÊA FILHO, L.; CORRÊA GIRADE, M.H.; FRANÇA, P. (Orgs.). Novos olhares sobre a gestação e a criança até os três anos: saúde perinatal, educação e desenvolvimento do bebê. Brasília: LGE Funsaúde, 2002. P.205-214.

, M.; GOLSE, B. Da transparência psíquica à preocupação materna primária: uma via de objetalização. In: CORRÊA FILHO, L.; CORRÊA GIRADE, M.H.; FRANÇA, P. (Orgs.). Novos olhares sobre a gestação e a criança até os três anos: saúde perinatal, educação e desenvolvimento do bebê. Brasília: LGE Funsaúde, 2002. p.215-220.

CASELlATO, G. Dor silenciosa ou dor silenciada: Perdas e lutos não reconhecidos por enlutados e sociedade. São Paulo: Livro Pleno, 2005.

CYRULNIK, B. Os alimentos afetivos e o amor que nos cura. São Paulo: WMF Martins Fontes, 1995. 
FREUD, S. Análise de uma fobia em um menino de cinco anos. In: FREUD, S. Duas histórias clínicas (o "pequeno Hans" e o "homem dos ratos")(1909). (Edição standard brasileira das obras psicológicas completas de Sigmund Freud. Vol. X). Rio de Janeiro: Imago, 1974, p.15-107 (Trabalho original publicado em 1909).

. Sobre o narcisismo: uma introdução. In: FREUD, S. A história do movimento psicanalítico, artigos sobre metapsicologia e outros trabalhos (19141916). (Edição standard brasileira das obras psicológicas completas de Sigmund Freud. Vol. XIV). Rio de Janeiro: Imago, 1974, p.85-119 (Trabalho original publicado em 1914).

. Luto e melancolia. In: FREUD, S. A história do movimento psicanalítico, artigos sobre metapsicologia e outros trabalhos (1914-1916). (Edição standard brasileira das obras psicológicas completas de Sigmund Freud. Vol. XIV). Rio de Janeiro: Imago, 1974, p. 271-291 (Trabalho original escrito em 1915 e publicado em 1917).

Inibições, sintomas e ansiedade. In: FREUD, S. Um estudo autobiográfico, inibições, sintomas e ansiedade, análise leiga e outros trabalhos (1925-1926). (Edição standard brasileira das obras psicológicas completas de Sigmund Freud. Vol. XX). Rio de Janeiro: Imago, 1974.p.107-198 (Trabalho original escrito em 1925 e publicado em 1926).

GARCIA-ROZA, L.-A. Introdução à metapsicologia freudiana. Rio de Janeiro: Jorge Zahar, 2004.

GOLSE, B. O bebê hoje: novos dados, esperanças e frustrações. In: GOLSE, B. Sobre a psicoterapia pais-bebê: narratividade, filiação e transmissão. São Paulo: Casa do Psicólogo, 2003. p.13-45.

GREEN, A. A mãe morta. In: GREEN, A. Sobre a loucura pessoal. Rio de Janeiro: Imago, 1988. P. 148-175 (Trabalho original publicado em 1980).

IACONELLI, V. Luto insólito, desmentido e trauma: clínica psicanalítica com mães de bebês. Revista Latino Americana de Psicopatologia Fundamental, São Paulo. Vol. 10, $\mathrm{n}^{\circ} 4$.

KLAUS, M.; KENNELL, J. Atendimento aos pais de um natimorto ou de um bebê que morre. In: KLAUS, M.; KENNELL (Org.). Pais/bebês: a formação do apego. Porto Alegre: Artes Médicas, 1992. P.276-307

LEBOVICI, S. O bebê, a mãe e o psicanalista. Porto Alegre: Artes Médicas, 1987.

LEWIS, E. The management of stillbirth: coping with an unreality. The Lancet, v. 308, n. 7986, p. 619-620, 1976.

MATHELIN, C.: O sorriso da Gioconda: clínica psicanalítica com os bebês prematuros. Rio de Janeiro: Companhia de Freud, 1999. 
MISSONNIER, S., L'enfant du dedans et la relation d'objet virtuel. In: MISSONIER,S.; GOLSE,B.; SOULÉ,M. La grossesse, l'enfant virtuel et la parentalité, Paris, PUF, 2004

O início da parentalidade, tornar-se mãe, tornar-se pai. As interações dos pais e da criança antes do nascimento. In : SILVA, M.C.P.; SOLIS-PONTON, L. (Orgs.). Ser pai, ser mãe - parentalidade: um desafio para o terceiro milênio. São Paulo: Casa do Psicólogo, 2004. p. 115-122.

Le premier chapitre de la vie : nidification parentale, didification foetale. La psychiatrie de l'enfant, Paris, v.50, n.1, p. 61-80, 2007.

Les stèles virtuelles sur Internet: un rituel de deuil séculier? Le

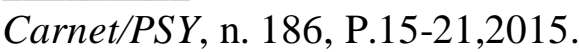

OGDEN, T. Os sujeitos da Psicanálise. São Paulo: Casa do Psicólogo, 1996.

On holding and containing, being and dreaming. In: Institute of Psychoannalysis, 2004; 85:1349-64

Esta arte da psicanálise: sonhando sonhos não sonhados e gritos interrompidos. In: Esta arte da psicanálise: sonhando sonhos não sonhados e gritos interrompidos. Porto Alegre: Artmed, 2010 p17-37.

OUTEIRAL, J.; MOURA, L. Paixão e criatividade: estudos psicanalíticos sobre Frida Kahlo, Camille Claudel e Coco Chanel. Rio de Janeiro: Revinter, 2002.

PINHEIRO, T. Trauma e melancolia. Percurso, n. 10, p. 50-55, 1993.

Ferenczi: do grito à palavra. Rio de Janeiro: JZE, 1995.

; QUINTELLA, R.; VERZTMAN, J. Distinção teórico-clínica entre depressão, luto e melancolia. Psicologia Clínica, vol.22, $\mathrm{n}^{\circ}$ 2. Rio de Janeiro, 2010.

O modelo melancólico e os sofrimentos da contemporaneidade. In: VERTZMAN, J; HERZOG, R.; PINHEIRO, T.; FERREIRA, F.P. (Orgs.). Sofrimentos Narcísicos. Rio de Janeiro: Cia. de Freud, 2012. p. 17-38.

ROMÃO-DIAS, D. Brincando de ser na realidade virtual: uma visão positiva da subjetividade contemporânea. Pontifícia Universidade Católica do Rio de Janeiro, 2007 (Tese de Doutorado).

ROUSSILLON, R. L'objet médium malleable et la Reflexivité. In: Le transitionnel, le sexuel et la réflexivité. Dunod, Paris 2008. P.37-50. 
SANTOS, N.; ZORNIG, S. Primeiros tempos da maternidade: indiferenciação ou intersubjetividade na relação primitiva com o bebê? Estilos da Clínica, v. 19, n. 1, São Paulo, 2014.

SAFRA, G. O narrar. In: SAFRA, G. Desvelando a memória do humano: o brincar, o narrar, o corpo, o sagrado, o silêncio. São Paulo: Sabornost, 2006. P.21-33.

SOLIS-PONTON, L.; LEBOVICI, S. Diálogo Solis-Ponton e Lebovici. In: SILVA, M.C.P.; SOLIS-PONTON, L. (Orgs.). Ser pai, ser mãe - parentalidade: um desafio para o terceiro milênio. São Paulo: Casa do Psicólogo, 2004. p. 21-27.

SOUBIEUX, M-J, Le berceau vide. Érès. Toulouse, 2008. p.22-24, 2015 .

Le deuil périnatal, un impensable à penser. Le Carnet/PSY, n. 185, .; CAILLAUD, I. Le groupe thérapeutique des mères endeuillées. Le Carnet/PSY, n. 186, p.2731, 2015.

STERN, D. A constelação da maternidade: o panorama da psicoterapia pais/bebê. Porto Alegre: Artes Médicas, 1997.

SZEJER, M.; STEWART, R. Nove meses na vida da mulher: uma aproximação psicanalítica da gravidez e do nascimento. São Paulo: Casa do Psicólogo, 1997.

TOROK,M. Doença do Luto e Fantasia do cadáver saboroso. In: ABRAHAM, N.; TOROK, M. A casca e o núcleo. São Paulo: Escuta, 1995 (Trabalho original publicado em 1968).

WINNICOTT, D. Objetos transicionais e fenômenos transicionais. In: WINNICOTT, D. O brincar e a realidade. Rio de Janeiro: Imago, 1975. P.13-44 (Trabalho original publicado em 1951).

- Preocupação materna primária. In: WINNICOTT, D. Textos selecionados da Pediatria à Psicanálise. Rio de Janeiro: F. Alves, 1978.p.491498 (Trabalho original publicado em 1956).

A criatividade e suas origens. In: WINNICOTT, D. $O$ brincar e a realidade. Rio de Janeiro: Imago, 1975. P95-120 (trabalho original publicado em 1959).

Teoria do relacionamento paterno-infantil. In: WINNICOTT, D. $O$ ambiente $e$ os processos de maturação: estudos sobre a teoria do desenvolvimento emocional. Porto Alegre, Artes Médicas, 1990. P.38-54 (Trabalho original publicado em 1960).

Os objetivos do tratamento psicanalítico. In: WINNICOTT, D. $O$ ambiente e os processos de maturação: estudos sobre a teoria do 
desenvolvimento emocional. Porto Alegre, Artes Médicas, 1990. P.152-155 (Trabalho original publicado em 1962).

Tudo começa em casa. São Paulo: Martins Fontes, 1999.

ZORNIG, S. A criança e o infantil em psicanálise. São Paulo: Escuta, 2008.

Tornar-se pai, tornar-se mãe: o processo de construção da parentalidade. In: Tempo Psicanalítico, vol. 42 no2, Rio de Janeiro jun. 2010.

Construção da parentalidade: da infância dos pais ao nascimento do filho. In: PICCININI,C. (org) Maternidade e paternidade: a parentalidade em diferentes contextos. São Paulo: Casa do Psicólogo, 2012. P17-34. 